JOSÉ POLO ACUÑa

José Polo Acuña es maestro en Historia por la Universidad Nacional de Colombia (1999) y es candidato a doctor en Historia por la Universidad Central de Venezuela. Se desempeña como profesor-investigador de la Universidad de Cartagena, Colombia. Su principal línea de investigación es la historia colonial y republicana de la frontera del Caribe colombiano. Sus más recientes publicaciones son: “Identidad étnica y cultura en una frontera del Caribe: La Guajira, 1700-1800", Aguaita, Revista del Observatorio del Caribe Colombiano, núm. 8, 2002, pp. 1331; "Poblamiento y conflicto social en la frontera Guajira, siglo xviII", El Taller de la Historia, Universidad de Cartagena, Programa de Historia, núm. 1, 2001, Cartagena, pp. 27-55, y “Los wayúu y los cocina: dos caras diferentes de una misma moneda en la resistencia indígena guajira, siglo xvm", Anuario Colombiano de Historia Social y de la Cultura, Universidad Nacional de Colombia, nuím. 26, 1999, pp. 7-27. 


\title{
CONTRABANDO Y PACIFICACIÓN INDÍGENA \\ EN LA FRONTERA COLOMBO-VENEZOLANA DE LA GUAJIRA (1750-1820)*
}

\author{
José Polo Acuña
}

INTRODUCCIÓN

$\mathrm{E}$ l comercio de contrabando y la hostilidad de los indígenas no reducidos fueron dos elementos que perturbaron el orden social y económico impuesto por las autoridades españolas en sus colonias americanas durante el siglo XVIII, problemas con los que igualmente tuvieron que lidiar las autoridades republicanas por lo menos en las dos primeras décadas del siglo XIX, por lo que buena parte de los esfuerzos gubernamentales se centraron en combatirlos. La necesidad de reprimir el trato ilícito estaba estrechamente relacionada con la tarea de pacificar y reducir a los grupos aborígenes hostiles a cualquier política de dominación, por cuanto ellos, a menudo, establecieron alianzas con contrabandistas extranjeros para beneficiarse mutuamente del tráfico. Los lugares

* Este trabajo es parte de la propuesta de tesis doctoral en historia que adelanta el autor para (decial y Cultura Fronteriza en la Guajira, 1700-1850. Parte de esta investigación se financió gracias al apoyo del Programa de Becas de Investigación Cultural Héctor Rojas Herazo, del Observatorio del Caribe colombiano. Agradezco igualmente a la Universidad de Cartagena por haberme concedido la Comisión de Estudios que me permitió desplazarme a Caracas. El Instituto Colombiano de Antropología e Historia (ICANH) está financiando igualmente la última parte de este trabajo mediante las ayudas a investigaciones en el área de historia colonial. Agradecimientos a los estudiantes del Programa de Historia de la Universidad de Cartagena, particularmente los que son parte del grupo de estudios sobre Frontera, Sociedad y Región, por sus diligentes y pacientes lecturas y críticas a lo largo de la investigación en sus diversas fases. 
afectados por esta situación fueron territorios fronterizos, caracterizados por la escasa presencia del Estado colonial y republicano, el despojo por parte de los colonos de la tierra y de otros bienes de los naturales o de los campesinos por medio del uso de la violencia que propugnaba por someterlos y controlarlos, zonas donde se presentaron planes y procesos de colonización y donde el mestizaje estuvo a la orden del día; en fin, lugares en que se dan interacciones entre dos o más culturas diferentes con lo que se produce una dinámica única en tiempo y espacio. ${ }^{1}$ Así ocurrió en algunas partes del Cono Sur, cerca de las estancias ganaderas de Cuyo y Chile, donde las tribus libres de la Araucania, por intermedio de sus jefes guerreros, lonkos, hicieron pactos directos con los traficantes ingleses quienes les compraban el ganado que hurtaban en las mencionadas estancias, lo cual dio origen a un dinámico intercambio ilícito en esa zona. ${ }^{2}$

De igual manera, en la extensa región noroeste de Brasil, los franceses establecieron alianzas con los indios tupinambá, las cuales les permitieron ejercer libremente el trato ilícito en las costas. ${ }^{3}$ Asimismo, en la costa nicaragüense, los indios miskitos mantuvieron activas relaciones de intercambio con los ingleses, quienes les propusieron crear en su territorio un protectorado británico totalmente independiente de la jurisdicción española.

Este artículo propone analizar el problema del contrabando y su relación con los intentos de pacificación de los indios en la Guajira durante la segunda mitad del siglo XVIII y las dos primeras décadas del XIX, asumiendo que un fenómeno como éste se vio favorecido por la coyuntura política y económica que afectó el Caribe durante el siglo XVII. Esta situación y sus múltiples efectos fueron enfrentados por las autoridades hispanas y los posteriores gobiernos de Venezuela y Colombia, respectivamente, con la adopción de políticas de pacificación que contaron con una gama de medidas que iban desde el uso de la fuerza por medio de la represión militar hasta los intentos de cooptación de los líderes indígenas, los cuales fueron vinculados a tales procesos como intermediarios mediante los cuales se pretendía sujetar a la población nativa. Consecuentemente, el contrabando y la pacificación indígena se convirtieron en dos elementos importantes de lo que Alejandro Grimson denomina procesos de fronterización, entendiéndolo como "los procesos históricos a través de los cuales los diver-

1 Para los usos del concepto de frontera de acuerdo con los diversos contextos en que se ha aplicado véanse Villalobos, Vida, 1992, p. 14; Weber, Frontera, 2000, pp. 25-29. Weber y Rausch, Where, 1994, pp. xIII-xL. Véase el útil atículo de Londoño, "Frontera", 2003. Los estudios sobre fronteras tuvieron un impulso inicial con la publicación de la ya clásica obra de Turner, Frontera, 1986.

${ }^{2}$ León "Invasione", 1986

${ }^{3}$ Hemming, "Indios", 1990, t. 4. 
sos elementos de la frontera son construidos por los poderes centrales y por las poblaciones locales. Este concepto pretende enfatizar que, desde el punto de vista sociocultural, la frontera nunca es un dato fijo, sino un objeto inacabado e inestable. Un objeto constantemente disputado de formas diversas."

De esta forma, la coyuntura política y económica que caracterizó al Caribe durante el siglo XVIII se diferenció notablemente de la reinante en los siglos XVI y XVII; en efecto, aunque las autoridades españolas consideraban el comercio de mercancías sin el reconocimiento del debido arancel a la corona española como una actividad ilícita, ésta se había expandido hasta lograr un cierto grado de legitimidad y tolerancia en el contexto internacional del Caribe, rompiendo de paso el monopolio comercial español. En este episodio desempeñan un papel importante las reconocidas posesiones de los extranjeros en territorios americanos del Caribe, Jamaica y Curazao; por ejemplo, brindaron a ingleses y holandeses la oportunidad de organizar abiertamente y por iniciativa privada un comercio de gran escala. Los franceses, por su parte, aprovecharon la alianza de Luis XIV con la España borbónica para llevar a cabo un tráfico directo desde puertos franceses a las Américas, lo que les permitió incursionar en los mercados del virreinato de Perú. ${ }^{5}$ En los siglos XVI y XVII las actividades de contrabando de los extranjeros en el Caribe tuvieron una menor cobertura y necesitaron para su realización del apoyo militar de los respectivos Estados, lo cual se expresó, principalmente, en forma de piratería armada. A diferencia de aquéllas, durante el siglo XVIII, la actividad fue realizada en forma abierta y fluida, gracias a las condiciones nuevas que caracterizaron el contrabando caribeño durante este periodo. Es así como en las provincias de Santa Marta y Riohacha el abastecimiento de productos se hizo por medio de un contrabando abierto $\mathrm{y}$, muchas veces, contaba con la complicidad de las mismas autoridades reales. La magnitud de la actividad ilícita se ve en su verdadera dimensión si se considera que en el periodo de 1700 a 1763 ningún barco mercante español arribó al puerto de Riohacha, por lo cual sus habitantes se abastecieron de productos básicos como ropa, alimentos, vinos e instrumentos de trabajo por medio de la negociación clandestina con los extranjeros provenientes de Jamaica y Curazao. ${ }^{6}$

El aumento del contrabando, debido a la creciente penetración de los extranjeros, sobre todo en espacios fronterizos alejados de las zonas de control, ayudó a consolidar las alianzas entre los indios y los trafican-

" Grimson, "Procesos", 2003, p. 17.
${ }^{5}$ McFarlane, Colombia, 1997, p. 158.

${ }^{6}$ Múnera, Fracaso, 1998, pp. 68-69. 
tes. En zonas como la Guajira, ${ }^{7}$ tal actividad atentaba directamente contra el dominio español, toda vez que permitió la adquisición de armas de fuego por parte de los indios guajiros, con lo que aumentó su capacidad militar de respuesta a las autoridades reales. Así, por ejemplo, en un conteo de indios guajiros auspiciado por Nicolás Gil Martínez, obispo de Santa Marta en 1763, se estableció una cifra de 7660 indios con capacidad de tomar las armas. ${ }^{8}$ Este número se incrementó en el año de 1779 a 14. 970 nativos. ${ }^{9}$ Aunque dichos números no reflejan necesariamente el aumento de armas, sí proporcionan un indicio de la circulación de rifles ingleses y holandeses entre la población nativa que iba en aumento.

Por consiguiente, el contrabando y la pacificación indígena en la Guajira durante la segunda mitad del siglo XviII y primeras dos décadas del XIX fueron dos problemas asociados a la nueva situación política y económica del Caribe, el cual, consolidado como mar interior americano, fue escenario de las luchas entre España y potencias como Inglaterra, Holanda y Francia. Las dos primeras tuvieron una influencia directa en el fomento de las actividades de contrabando y en la "animadversión" de los indios guajiros en contra de las autoridades hispanas. Al respecto, la política de la corona española consistió en desplegar estrategias y medidas enmarcadas en una serie de transformaciones fundamentalmente económicas y defensivas establecidas tanto en España como en América. Sin embargo, estas estrategias y medidas aplicadas en la Guajira chocaron de manera frontal con la comunidad wayúu, un pueblo forjado en è marco de guerras entre clanes que venían dándose desde siglos atrás, por lo que las operaciones militares de las autoridades hispanas no les fueron totalmente ajenas y antes, por el contrario, eran parte de su diario vivir.

\section{La Guajira en laS disputas imperiales por el CARIBE}

Desde el segundo cuarto del siglo XVII, Holanda, Francia, Inglaterra y, con posteridad, Dinamarca, ocuparon permanentemente algunos territorios en Hispanoamérica que España tenía en relativo abandono, ya por-

${ }^{7}$ La península de la Guajira es el espacio más septentrional de Colombia y noroeste de Venezuela, está localizada al norte del macizo de la Sierra Nevada de Santa Marta y de los montes de Oca y entre el Mar Caribe al oeste y norte, y el Golfo de Venezuela al este. Su 12000 corresponden a Colom y 3380 a Venezuela.

8 "Padrón de los indios capaces de tomar las armas en cada población", 1973, en Archivo General de la Nación (en adelante AGN), Milicias y marina, 124, f. 586 .

Archivo General de Indias (en adelante AGI), Santafé, 702, D. 12; Tovar, Convocatoria, 1994, pp. 531-539. 
que fueran terrenos inhóspitos o estériles, o porque sus belicosos habitantes no los dejaban poblar, o porque no poseían metales preciosos. Así, por ejemplo, desde muy temprano, en 1602, los holandeses crearon la Compañía de las Indias Orientales, "cuya finalidad fundamental era desplazar a Portugal del comercio de las especias, por la ruta del Atlántico meridional y hacerle frente a las compañías pequeñas inglesas en el Báltico". ${ }^{10} \mathrm{Al}$ mismo tiempo se interesaron por las salinas de Araya, en territorios aledaños a Cumaná, en el Caribe venezolano. Posteriormente, en 1621, conformaron la Compañía de las Indias Occidentales que valida del triple método de colonizar, realizar pillaje y contrabandear en gran escala, se encargó de hostigar las posesiones españolas en América. Su blanco inicial fueron las costas del noroeste de Brasil, para aprovechar las plantaciones de azúcar y el potencial de las maderas de tinta para textiles. Entre 1624 y 1625 se apoderaron de Pernambuco, Paraíba, Sergipe, Río Grande del Norte y Manahao. En forma efímera se establecieron en la Guayana o Costa Salvaje, entre el Orinoco y el Amazonas. En este primer cuarto del siglo XVII fundaron las colonias de Berbice, Esequibo, Pomeroon y Surinam, esta última cedida por Inglaterra en el Tratado de Breda en $1667 .{ }^{11}$ Luego, en el segundo cuarto del siglo XVII se establecieron en las Antillas Menores y desalojaron a los españoles de Curazao al mismo tiempo que ocupaban a Aruba y Bonaire. La primera de estas tres islas operó como punta de lanza de sus incursiones por el Caribe y en la Guajira.

Los ingleses, por su parte, se apoderaron de otras islas antillanas. Jamaica pasó a sus manos en 1655, así como Barbados, Bermudas, Anguila, San Cristóbal, San Kitts, Tortuga, Antigua, Nevis, Barbuda y Tobago. Desde ellas afianzaron su presencia en puntos vitales de las costas del Norte y Centroamérica: Laguna de Términos, Bélice, Islas de la Bahía, de Maíz y Mosquitia y las de Providencia y San Andrés, y compartieron con los holandeses la Guayana. De todas estas islas, Jamaica fue importante porque se convirtió en eje de actividades de piratería y sirvió de base para el comercio ilícito en el Caribe. A diferencia de Curazao, cuyo suelo era estéril, Jamaica se caracterizó por su fertilidad para el cultivo de la caña de azúcar. Estas dos islas, Curazao y Jamaica, fueron puntos clave desde donde ingleses y holandeses incursionaron en territorio guajiro. A su vez, los franceses se establecieron en San Bartolomé, San Vicente, Dominica, Martinica, Granada, Guadalupe y el norte de Santo Domingo, en tanto que los daneses tomaron Saint Thomas, Santa Cruz y los cayos de San Juan. Las costas de la península de la Guajira, en

\footnotetext{
${ }_{10}^{10}$ Araúz, Contrabando, 1984, t. i, p. 23

${ }^{11}$ Ibid., p. 26.
} 
consecuencia, hicieron parte de un conjunto de territorios disputados a España por diversas naciones presentes en el escenario del mar Caribe. En el siglo XvIII sucedieron muchos cambios en Europa y en Hispanoamérica. "El Caribe se convirtió en un escenario de primer orden: allí se definieron algunas acciones decisivas en la pugna por el poder mundial; adicionalmente las confrontaciones entre potencias europeas tuvieron un impacto directo en los territorios insulares y ribereños, y provocaron transferencias de soberanía." ${ }^{2}$ En efecto, los tratados de paz signados en Utrech entre 1713 y 1715 dieron término a la guerra de Sucesión espanola y crearon un nuevo equilibrio de poderes. La coparticipación fortaleció a Gran Bretaña al concederle mayores ventajas económicas que a Holanda y Francia, lo cual se reflejó en el contexto internacional del siglo XVIII, pues en el Caribe, por ejemplo, se afirmó la preponderancia británica. Esta afirmación se materializó en concesiones españolas como el permiso para que un navío de 500 toneladas fuera enviado anualmente con mercancías inglesas para ser vendidas en las ferias, o la transferencia, por 30 años, del asiento de los negros que fue otorgado en 1701 por Felipe V a la compañía francesa de Guinea con el consiguiente rompimiento del monopolio comercial de España con sus colonias. ${ }^{13}$ Los ingleses aprovecharon su influencia en la zona para fortalecer su dominio como quedó patente en 1722 , cuando reclamaron al gobierno danés la soberanía sobre las islas de Saint Thomas y Saint John y en 1730 a Francia sobre las de Barlovento, Santa Lucía, Saint Vicent y Dominica. Su interés por estos puntos era estratégico y económico, pues, desde el siglo XVII, las islas danesas habían servido como puente para colonizar el Caribe y como posibles bases para el ejercicio del contrabando.

El papel de Jamaica en la estrategia británica respecto al Caribe se refleja en el hecho de que

fue importante como base de operaciones de los piratas y filibusteros británicos que, auspiciados por la corona, no dejaban pasar oportunidad de asaltar cuanto convoy español cruzara por el Caribe. Más tarde, ante el aumento del consumo de azúcar en Europa, Jamaica se va convirtiendo poco a poco en gran productor de caña de azúcar y su principal derivado, el ron. La isla se transforma en un conglomerado de plantaciones con uno de los más altos índices de población esclava. ${ }^{14}$

12 Clemente, "Virreinato", 1989

${ }^{13}$ Ibid.

14 Bell, "Conexión", 1986. 
Así como disminuyó la actividad de los piratas con base en la isla aumentó el número de tratados de comercio, de tal forma que las manufacturas inglesas inundaron su mercado y se crearon varias firmas comerciales con socios en Londres y Kingston. Desde esta ciudad se exportaba azúcar, ron, cacao, esclavos de África y sal de las islas adyacentes; a ella llegaban cristales, telas, prendas de vestir y cualquier producto que Europa exportara al resto del mundo, lo cual la convirtió en un gran depósito de mercancías inglesas en busca de mercados. ${ }^{15}$ Hacia allí fueron llevadas las mulas criadas en la Guajira, las perlas pescadas y los esclavos indígenas capturados en la península. Tal actividad requirió del envío de emisarios comerciales desde y hacia Riohacha.

Curazao fue para los holandeses, lo que Jamaica para los ingleses. A pesar de no contar con agua, se convirtió en un puerto libre por el que circularon los productos de las pequeñas salinas $\mathrm{y}$, fundamentalmente, $\mathrm{e}$ palo brasil. "No obstante, constituyó una valiosa adquisición por su posición estratégica -lo llamamos ventaja posicional-, al estar encima de la tierra firme y de fácil acceso a las islas antillanas en manos de España, o las que pasaron al poder de Inglaterra, Francia y Dinamarca." ${ }^{16} \mathrm{~A}$ las radas de Curazao arribaban al año entre 30 y 40 navíos y unas 400 balandras dedicadas al tráfico alrededor del Caribe. En este sentido la isla se convirtió en un centro importante para el comercio clandestino de Holanda en el Caribe, sobre todo después del fracaso de la compañía de las Indias Occidentales en Brasil; además porque a los holandeses no les quedó otra alternativa toda vez que en el Tratado de Utrech se relegó su competencia a Europa, quedando excluida de los mercados hispanos. De Curazao arribaban naves y balandras holandesas a las costas guajiras en busca del palo brasil que extraían los indios guajiros de los montes de Oca.

\section{El CONTRABANDO}

La situación internacional que se vivía en el siglo XVIII, caracterizada por dos formas de ejercicio comercial, en medio de las cuales se posibilitó el surgimiento de la actividad del contrabando, realizado en la costa caribeña de Nueva Granada, es descrita por Antonio García de la siguiente manera:

Las leyes del desarrollo capitalista demostraron tener mayor fuerza práctica que las leyes prohibitivas, represivas y casuísticas del Estado español. Desde finales del siglo xvm (diríamos más bien desde el principio), el comercio de

${ }^{15} \mathrm{Ibid}$.

${ }^{16}$ Araúz, Contrabando, 1984, t. I, p. 12. 
contrabando -esto es, el correspondiente al nuevo tipo de comercio internacional, promovido e impulsado por potencias europeas forjadas en la revolución industrial y en los victoriosos movimientos democráticos-burgueses en Holanda, Inglaterra y Francia- se convirtió para la Nueva Granada en una forma comercial dominante, no sólo por el regular y franca utilización de las vías ya definitivamente abiertas en la Guajira y el Darién, sino por la casi total suspensión del comercio oficial con la metrópoli. ${ }^{17}$

En efecto, Antonio de Arévalo, en la segunda mitad del siglo XVIII, denunciaba que en toda la costa de sotavento y barlovento de Riohacha fondeaban las balandras extranjeras y españolas en los puertos menores de la Enea, puerto de la Cruz Vieja, El Pajar, Almidones, Manaure y Tucuraca; Uñama, Carrizal, Rincón del Carpintero, Cabo de la Vela e Iriguani; los puertos mayores de Bahía Honda y Puerto Taroa, Punta Gallinas, Chimare y Cabo de Chichivacoa; Sabana del Valle, Tucacas y Cojoro. ${ }^{18}$ Es decir, que los contrabandistas ingleses y holandeses traficaron con libertad todo tipo de mercaderías en los distintos puertos naturales de la península guajira de la misma manera en que lo habían hecho en otras zonas de frontera como la Guayana, la Mosquitia y el Darién, entre otras, en donde lograron ganar la confianza y contar con la ayuda de los indios a quienes estimulaba la animadversión contra las autoridades españolas. A esta situación aludía Francisco Silvestre en los siguientes términos:

La mayor parte de la provincia le ocupan las varias parcialidades de los bárbaros indios goagiros, con considerables porciones de ganado de asta y caballos, copiosas salinas y otros útiles frutos que comercian con los extranjeros, especialmente con los holandeses de Curazao en aquella dilatada costa, y además de los cueros, mulas y caballos, el palo del Brasil, en cuyo cambio los proveen de armas de fuego, pólvora y otros pertrechos: de manera que cada una de aquellas grandes parcialidades inmediatas a la costa suele tener su propio puerto, a donde vienen los extranjeros a tratar con ellos. ${ }^{19}$

En la costa atlántica de Nicaragua y en la Mosquitia, donde se producía añil, zarzaparrilla, caña de azúcar, cueros y maderas, los ingleses establecieron con el pueblo indígena misquito pactos directos ${ }^{20}$ en la Guayana los neerlandeses suministraron armas a los indios caribes con la contra-

${ }^{17}$ García, "Conflicto", 1981.
${ }^{8}$ Informe sobre la situación, condiciones materiales, población e historia de la provincia de Riohacha, por don Antonio de Arévalo. Año de 1773" (en adelante esta información se citará como Arévalo, indicando el número del folio), en AGN, Milicias y marina, 119, f. $452 \mathrm{v}$.

${ }_{19}$ Silvestre, Descripción, 1968 , p. 51.

${ }^{20}$ García, Comuneros, 1981, pp. 119-128. 
prestación de recibir el tabaco de Barinas, mulas, cueros y esclavos indios. ${ }^{21}$ En la Alta Guajira, se llevaron a cabo negociaciones entre los holandeses y los caciques indígenas pertenecientes a apüshis ${ }^{22}$ poderosos de:

cuyos puertos son poseedores de ellos los rebeldes indios guajiros, quienes con la mayor despotiquez, y desvergüenza, protegen con todas sus fuerzas, despreciando cualquier riesgo, el comercio holandés, por cuya nación se les contribuye con ello, bebidas, y otras cosas; y para asegurar su trato en aquellos puertos, y caletas, pasó y llevaron en el año de cincuenta y dos [1752], con toda comodidad, y atención particular, del indio Caporinche [capitán y cabeza de una gruesa parcialidad que mantiene a sus expensas con el mucho ganado que posee] a la isla de Curazao, e hicieron los holandeses con este indio formal convenio, de que siempre sería su protector, a cuyo fin lo recibieron en aquella isla con muchas fiestas, vistiéndolo, y a los que llevó consigo de su parcialidad, costosamente con casacas, pelucas y demás, haciéndole a la entrada y salida, una salva de quince cañonazos; y lo despacharon con una embarcación armada, después de haberle regalado porción de armas, como fusiles, sables, pólvora y plomo, remitiendo con dicho Caporinche a el indio Majusare [otro capitán de una muy gruesa parcialidad que tiene a su devoción, en mayor número que Caporinche, como es el más poderoso de aquella nación por la muchedumbre de ganado vacuno y caballar y de que mantiene su parcialidad, siendo estos dos indios compañeros y parientes, protegiéndose el uno del otro] algunos presentes y cartas muy afectuosas, para lograr los holandeses tener a su devoción a uno y otro, y asegurar por este medio y protección su trato y comercio ilícito en aquellos parajes. ${ }^{23}$

Entre los géneros recibidos por los indios guajiros, como fruto de la actividad del contrabando, estaban las armas de fuego, empleadas posteriormente en los ataques contra los españoles como en las protestas de 1769, la de Apiesi en 1775 y el ataque a Bahía Honda en 1776. Las armas de fuego y el caballo fueron dos elementos importantes en la sociedad wayúu, donde la guerra desempeñaba un papel como eje estructurador que permitía la recomposición del poder y las fuerzas en la comunidad, como veremos posteriormente. La finalidad de estos intercambios, como se ve, no era solamente comercial, sino también política, pues aparte de suministrar armas y otros géneros a los indios, los extranjeros asumieron la instrucción en el manejo de aquéllas y en la ejecución de tácticas mili-

${ }^{21}$ Araúz, Contrabando, 1984, t. I, p. 45.

${ }^{22} \mathrm{El}$ apüshi es un grupo residencial de hermanos y hermanas maternos, asentados en un

territorio en el cual tienen sus huertas, pozos de agua y cementerio.
${ }^{23} \mathrm{AGN}$, Caciques e indios, 4 , fs. $647 \mathrm{r}$ y v, año 1757. 
tares de emboscada a las autoridades reales. Así, por ejemplo, en octubre de 1775 , un capitán inglés de nombre Constantino, que se hallaba en los puertos de Sabana del Valle y Chimare, en la Alta Guajira, vendió a los indios armas, pedreros y municiones, e instruyó a muchos de ellos en el manejo de los pedreros de barca, "encargándoles las pusiesen en los caminos por donde debían pasar los españoles y que hiciesen excavaciones colocando en ellas rayas envenenadas y que las cubrieran de ramas para que no fuesen conocidas". ${ }^{24}$

Por otro lado, la extracción del palo brasil de los montes de Oca resultaba atractiva y de mayor lucro para los neerlandeses, pues se decía que la variedad y viveza de los tintes que daba excedía en calidad al sacado de Campeche por los ingleses. "Los holandeses [...] han sacado millares de cargas que vendían en Curazao a ocho, y diez, y hasta 16 pesos." 25 De igual forma por Riohacha salían numerosas mulas para las plantaciones de Jamaica y Surinam y se enviaban clandestinamente a Cuba para ser empleadas en las haciendas de trapiche ${ }^{26}$ La actividad de los barcos ingleses provenientes de Jamaica que arribaban a un sector costero comprendido entre el Cabo de la Vela y Carrizal tenía por objeto la pesca de tortugas, pues de su caparazón se extraía el Carey. ${ }^{27}$ Antonio de Narváez y la Torre había advertido sobre este recurso:

Abunda mucho toda esta costa de las tortugas de carey de que toma el nombre la concha que de ella se saca; pero como no hay gentes dedicadas a su pesca, ni se ha pensado en hacer ésta rama de comercio, sólo se consigue tal cual por casualidad cogen los indios; y más bien que nosotros se aprovechan de esta producción de nuestros mares los ingleses, que en guayres, y balandras pequeñas vienen a pescar, tortugas a esta costas en las estaciones favorables. ${ }^{28}$

La esclavitud y el comercio de esclavos negros por medio del contrabando fueron comunes en la Guajira, pues indios e hispano-criollos de la provincia poseían "piezas" que, en su mayoría, habían sido suministradas por los tratantes extranjeros. A menudo, los guardacostas reales apresaban balandras con mercaderías y negros esclavos. "Más de seis leguas a sotavento de esta ciudad [Riohacha] tuvo su comandante denuncio sobre una balandra inglesa acosada de un corsario francés, y que su capitán y tripulación, y algunos negros se hallaban en tierra, a lo que su celo dispu-

${ }^{24}$ AGN, Milicias y marina, 11, f. 894r, año 1775

25 "Informe", 1965, p. 27.

${ }^{26}$ Ortiz, Escritos, 1965, p. 28

AGN, Milicias y marina, 20 f. 393v, año 1773

${ }^{28}$ Ortiz, Escritos, 1965, pp. 31-32. 
so la marcha para la segura recaudación del quinto."29 El número de esclavos comprados ilícitamente por los indios no se conoce; sin embargo, su cifra bien pudiera ser significativa si se tiene en cuenta que las autoridades reales concedieron periódicamente indulto a los líderes indígenas que llevaran sus negros a marcar. ${ }^{30}$ Además de los negros, había un comercio de esclavos indígenas capturados por los guajiros y vendidos a extranjeros de Jamaica y Surinam como mano de obra para las plantaciones de caña. Tales indios eran los llamados cocinas, segmento étnico ${ }^{31}$ guajiro de los que el discurso colonial construyó una imagen de ladrones y saqueadores, y que fue despreciado por los clanes matrilineales wayúu. Tal percepción es descrita por Antonio de Arévalo en 1773, cuando afirma que:

estos indios andan dispersos por la tierra haciendo daños sin tener casa ni hacienda ninguna, y son enemigos de todos los demás de la provincia, y en tal manera malquistos, que se agravian éstos de que se les digan que son cocinas porque esto quiere decir tanto como que son unos levantados ladrones; por cuyas razones está recibido y corriente entre todos, que los hijos pequeños, que les cogen los venden en la costa y a los demás que se los compran [de los cuales hay aquí algunos], y los ingleses han sacado muchos de Bahía Honda y Portete, de los cuales el Jorobado [capitán inglés] sacó 60 en diciembre próximo pasado, y todos llevan algunos comprados muy baratos y los llevan a Jamaica y vender por esclavos para Filadelfia y aquella costa. ${ }^{32}$

Esto nos está mostrando que la comunidad indígena de la Guajira no era homogénea; por el contrario, las autoridades hispanas tuvieron que lidiar con diferentes variables que incluía no solamente la segmentación étnica, sino también las diferencias y contradicciones entre los distintos

${ }^{29}$ AGN, Negros y esclavos-Panamá, fs. 583-600, año 1757; Moreno y Tarazona, Materiales, 1984 , p. 57.

AGN, Milicias y marina, 138, fs. 916-921, año 1753; Moreno y Tarazona, Materiales, 1984, p. 45 ${ }^{31}$ Entendemos el segmento étnico como la escisión de un linaje o de un clan producto del entido la presión por los recursos se hace más aguda y e mantenimiento de la organización comunal se vuẹve más compleja, por lo que las comunidades optan por la división para superar estos problemas. En la Guajira los cocina -y también los añú o paraujanos- son considerados por algunos investigadores como segmentos étnicos de los wayúuguajiro, que comenzaron su separaciôn cientos de años antes de la llegada de los europeos. Este tipo de segmentación étnica que se dio en la Guajira pertenecería al tipo de serie lineal de linajes, debido a que no se fusionan sino que simplemente se encuentran uno junto al otro. Los segmentos étnicos conservan durante algún tiempo el recuerdo de su tronco principal pero con el tiempo lo "olvidan". Los cocina y los añú tienen con los wayúu-guajiro afinidades etnolingüísticas. Para una definición de segmento étnico, véase Fox, Sistemas, 1979, pp. 113134. Respecto a la coexistencia de wayúu-guajiro y wayúu-cocina, Oliver, "Reflexiones", 1990,
pp. 81-135; Pérez, Wayuunaiki, 1998, pp. 15-22. Jusayú y Olza, Diccionario, 1988, pp. v-xvII, Jahn, Aborígenes, 1927, pp. 119-197. 
clanes wayúu, que a menudo sostenían guerras internas, producto de agravios recíprocos y que a veces terminaban con la recomposición de las fuerzas claniles.

La pesca de perlas o actividad del peruleo fue otro rubro importante del comercio ilícito en la Guajira, se llevaba a cabo entre el Carrizal (inicialmente fundada en la ciudad de los Remedios o Río de la Hacha y fue abandonada posteriormente por carecer de agua dulce en sus inmediaciones) y el Cabo de la Vela. Recuérdese que, a mediados del siglo XVI, el agotamiento de los ostrales en las costas de Cubagua en Venezuela determinó el traslado de numerosas familias hispanas a las costas occidentales de la península de la Guajira donde establecieron la pesquería. La mano de obra empleada era de negros esclavos y de indios provenientes unos del oriente de Venezuela, otros de las islas Lucayas, Margarita, Trinidad y Santo Domingo. También se ocuparon indios traídos de Brasil, Santa Marta, Valledupar y Mompox, pertenecientes a grupos y pueblos como los onotos, caracas, caquetíos, piritas, cumanagotos, chuaos, guaricos y maracapanes.

Esta actividad se fue trasladando hacia el suroccidente, bordeando la costa hasta quedar en la nueva ciudad de Riohacha, cerca de la desembocadura del río Ranchería (Calancala), lo cual la envolvió en un aire de prosperidad que hizo famosa la calle de la Platería o de la Mar, en donde hábiles enjoyadores procesaban las perlas. ${ }^{33} \mathrm{El}$ ambiente de prosperidad fue percibido por las autoridades hispanas que procedieron a establecer una caja real con el fin de obtener el derecho del quinto. ${ }^{34}$

Sin embargo, en 1721, a raíz del surgimiento de problemas con los indios buzos, en un informe de don Francisco de Alcantud y Gaona, capitán de infantería del batallón fijo de Cartagena, se planteó al virrey la posibilidad de introducir esclavos negros para hacer este trabajo. "Por lo que mira a la pesquería de Perlas, lo que me parece conveniente es que los 100 negros piezas de indias, mandará su majestad fuesen muleques de a dos por uno o tres por dos; que no es necesario sean buzos, que siendo de esta calidad muchos, presto aprenderán y serán ágiles fácilmente para todo el ministerio de buceo." ${ }^{35}$ La complicación en el desarrollo de la actividad conllevó a que en el siglo XVIII tal explotación prácticamente desapareciera como empresa lucrativa para los españoles a raíz de que los ostrales estaban en proceso de agotamiento y que los indios

${ }^{33} \mathrm{Al}$ respecto puede verse el trabajo de Vásquez y Correa, Relaciones, 1988. De igual forma el artículo de Guerra, "Ranchería", 1997. Un estudio más completo sobre las actividades perleras es el de Otte, Perlas, 1977. Asimismo, véase Julián, Perla, 1951, pp. 35-48.

${ }_{34} \mathrm{Al}$ respecto pueden verse las cifras transcritas por Tovar, Imperio, 1999, pp. 103-136.

${ }_{35}$ "Informe de don Francisco de Alcantud y Gaona al virrey sobre el estado de la provincia y ciudad de Riohacha. Año 1721", en AGN, Miscelánea, 60, fs. 576v y 577r. 
guajiros los habían expulsado, adueñándose de la costa y de los sitios de pesca. El mayor temor de los españoles consistía en que el beneficio de la actividad era usado por los nativos para adquirir armas y pólvora.

El peruleo y su organización bajo la explotación de los indígenas fueron descritas así por Antonio de Arévalo en 1773:

Al amanecer volvió la lancha a tierra. Se mandó aviso a Pacho Gámez a su casa que está a $1 \frac{1 / 2}{2}$ leguas de la costa, y pasaron a bordo de la balandra seis indios en un cayuco [canoa] grande [...], en tierra se hallaron hasta 120 indios, doce cayucos, que sirven para la pesca de perlas en aquellas costas; que hay ocasiones, como es en octubre, que está la mar muy sosegada, que salen de 60 a 70 cayucos con dos o tres indios cada uno, a hacer la pesca en tres brazas de fondo y no más; y los vecinos de la ciudad de los Remedios del Río de la Hacha pasan allí a hacer el rescate, llevando varias especies de víveres, coral, abalorios y otras cosas para hacerle. $\mathrm{Y}$ es, sin duda, el renglón de conocida utilidad que tienen aquellos vecinos, pero muchos años hace que los quintos de su majestad no han tenido valor. Esto no hay duda que consiste en poco cuidado y mal gobiemo de los que deben celarlos, porque todos buscan utilizarse en este trato.

A renglón seguido, aconsejaba que:

Para el fomento de la pesquería de las perlas en aquella costa, para tener este camino del Río de la Hacha a Bahía Honda abierto y corriente con el tráfico de los viajeros y tener una centinela continua y avisos frecuentes de los tratantes de la costa, conviene juntar un pueblo de los indios buzos de aquellas cercanías del mando de Pacho Gámez, haciéndole a êl capitán y teniente al que hubiere." ${ }^{36}$

Los ingresos dejados de percibir por la corona española fueron calculados por Antonio de Narváez y la Torre, quien señaló que el total de los valores reales entre los géneros que los extranjeros y los vecinos del Río de la Hacha llevaban a los indios para que éstos les rescataran las perlas, ascendía a 3000 o 4000 pesos; en tanto que las perlas procesadas y taladradas por los enjoyadores sumarían entre 16000 y 30000 pesos. ${ }^{37}$ Era, pues, un imperativo para las autoridades reales sujetar y pacificar a los indios buzos, para luego restablecer la pesquería de las perlas pero con el uso de mano de obra negra esclava, así lo sugirió Francisco Silvestre en su informe sobre el estado del peruleo en las costas guajiras hacia $1789 .^{38}$

${ }_{37}^{36} \mathrm{AGN}$, Historia civil, 20, fs. 537v y 538r, año 1773.

${ }^{38}$ Silvestre, Descripcion, 1968 , pp. $50-51$ 
El problema del contrabando se agravó toda vez que las autoridades encargadas de reprimirlo resultaron involucradas en él. Por ejemplo, en marzo de 1716, José Mozo de la Torre, gobernador de Santa Marta, informó al rey que en Bahía Honda el sacerdote apóstata José Pimienta traficaba con los indios guajiros en una balandra, cuyos dueños eran mercaderes judíos de Curazao, les suministraba los géneros acostumbrados y también armas para sus levantamientos contra los vecinos de Riohacha. ${ }^{39}$ El contrabando se extendía, pues las mercaderías ilícitas eran internadas hacia Quito y Lima, donde les era pagada con plata y oro en polvo. Para contrarrestar los efectos corruptores del contrabando en la Guajira, Bartolomé Tienda de Cuervo sugería al virrey, en 1718, incrementar los salarios de los funcionarios reales y de la tropa con el fin de que no tuvieran necesidad de enriquecerse mediante su ejercicio: ${ }^{40}$ "teniendo presente el continuado delito de estos vecinos y habitantes por el comercio ilícito que tantos años han tenido con los extranjeros y enemigos de la corona". ${ }^{41}$ Tienda de Cuervo sugería, además, la necesidad de utilizar guardias móviles, terrestres y marítimas, y no puestos fijos, debido a la dilatada extensión que debían controlar. Sin embargo, los ingresos generados por la actividad ilícita -unos 3000000 de pesos anualmente- ${ }^{42}$ fueron suficiente motivo para que la situación perdurara durante el siglo xVIII. Al respecto, Antonio de Arévalo, pacificador de la Guajira entre 1772 y 1776, describe la situación:

El rescate de las perlas que hacen a los indios de la Costa del Carrizal, el cambio de género, víveres, tabaco y otras cosas semejantes, su beneficio y venta, la del ganado y mulas y el trato ilícito que ha tenido la provincia con extranjeros y los vecinos de la jurisdicción del valle ha mantenido a los españoles de ella establecidos en esta ciudad y sitios o lugares, comprando los géneros y demás que han necesitado de ilícito trato con extranjeros, sacando éstos los frutos de la provincia y los que han conducido del Valle de Upar, en lo cual se han empleado de muchos años a esta parte haciendo ya naturaleza envejecida costumbre que han ejercitado sin freno y $\sin$ reconocimiento al soberano como sus vasallos, ni a la superioridad del virrey; considerándose como una rochela separada del dominio real porque siempre han hecho lo que han querido con unos de sus tenientes de gobernadores, doblándolos a su arbitrio, a otros sujetándolos con amenazas, concurriendo todos a la maldad. ${ }^{43}$

Araúz, Contrabando, t. I, p. 99

${ }_{40}^{40}$ Ibid., pp. 259-261.

${ }^{41} \mathrm{AGN}$, Miscelánea, 60, f. 581r, año 1773.

${ }^{42}$ Grahn, "Contraband", 1985, p. 17.

${ }^{43}$ Arévalo, f. 455r. 
La Guajira fue, en consecuencia, un territorio con mayor vinculación al contexto del Caribe que al interior andino, debido en parte a la pugna de las potencias extranjeras contra España. Éste fue también el escenario propicio para operaciones de contrabando, una de las armas usadas por Inglaterra y Holanda para minar el mercantilismo español. En el desarrollo de esta actividad participaron principalmente los indios guajiros. criollos, peninsulares, y las llamadas castas lo hicieron en menor proporción.

ESTRATEGIAS DE PACIFICACIÓN DE LA POBLACIÓN INDÍGENA Y EL. PAPEL DE LA GUERRA EN LA SOCIEDAD WAYÚU

Las diversas estrategias utilizadas por la corona para establecer y consolidar su dominio sobre la península y sus habitantes, así como para impedir los contactos entre los indios guajiros y los extranjeros, pueden ser resumidas fundamentalmente en tres: la primera encaminada al uso de los medios persuasivos, a cargo de los cuales estuvieron los misioneros capuchinos. La segunda, también de naturaleza persuasiva pero más orientada a la intervención política entre los grupos, intentó la cooptación de autoridades y líderes indígenas influyentes para someter más fácilmente a las distintas parcialidades. Y finalmente, la tercera, basada en la guerra, cuyo uso en las expediciones militares permitió el arrasamiento de muchas rancherías, a lo cual respondieron los nativos precisamente con ese mismo elemento que no les era ajeno, antes por el contrario hacia parte del funcionamiento de su sociedad.

\section{LAS MISIONES CAPUCHINAS}

Las misiones capuchinas que trabajaron en los procesos de evangelización en Hispanoamérica asignaron frailes provenientes de una misma provincia religiosa en España a las misiones localizadas en un territorio particular. Así fue como los frailes andaluces desarrollaron su labor en Venezuela, los catalanes en la Guayana, los aragoneses en Cumaná y los navarros y valencianos en la provincia de Maracaibo. ${ }^{44}$ La jurisdicción de esta última abarcó un territorio amplio entre Maracaibo y Santa Marta que comprendía, a grandes rasgos, desde las costas orientales del Golfo de Maracaibo hasta el río Magdalena por el occidente, tenía al norte el mar Caribe y llegaba por el sur hasta la ciudad de Ocaña.

${ }^{44}$ AgI, Caracas, 968, citado por Carrocera, Misión, 1968, t. III, p. 568. 
Los capuchinos valencianos llegaron a América por primera vez en 1647 y a la Guajira en 1693, y un año después se fundó la primera casa misional en la aldea de San Nicolás de los Menores en y La Cruz, dos poblados indígenas cercanos a Riohacha. Sin embargo, un movimiento armado de los indios cocinas en 1701 obligó a sus misioneros a retirarse a su sede en Maracaibo. Acto que fue respaldado mediante una real cédula del 4 de abril de 1702 en la cual el rey ordenó a los dos frailes que estaban en Menores y La Cruz pasar a Maracaibo. ${ }^{45}$ Durante los siguientes trece años, los indios guajiros no tuvieron en su territorio ningún misionero. Solamente a partir de 1715 en que el obispo de Santa Marta, Antonio Monroy y Meneses, nombró a dos de ellos en calidad de interinos para los pueblos de La Cruz y Menores. ${ }^{46}$ Esto fue posible por el traslado de once religiosos con el propósito de llevar a la "conversión de los indios guajiros, entre Maracaibo, y la del Río del Hacha, por ser de condición más tratable y poder resultar de su logro, muchas utilidades a la Real Hacienda y conveniencia a los vecinos de aquella jurisdicción" ${ }^{47}$ El traslado de estos religiosos se realizó porque los indios de Mérida y la Grita, provincia de Maracaibo, "se rebelaron y quemaron la iglesia, imágenes y ornamentos e hicieron otras atrocidades". ${ }^{48} \mathrm{El}$ traslado de los capuchinos a la provincia del Hacha fue autorizado por una real cédula de noviembre de 1717, por la cual se confería a los padres capuchinos la misión de evangelizar y pacificar a los indios guajiros. ${ }^{49}$ Un año después se efectuó una ratificación, la cual iba más allá, al plantear la posibilidad de nombrar como prefecto de las misiones solamente a religiosos de la orden capuchina, pues la experiencia había demostrado que en los trece años en que el territorio estuvo sin misioneros capuchinos, quienes les sucedieron, es decir, los presbíteros clérigos nombrados por el obispo de Santa Marta, no habían hecho ningún avance significativo. ${ }^{50}$ En lo sucesivo, los religiosos capuchinos trabajaron en concordancia con el gobernador de Santa Marta, don Juan Beltrán de Caycedo, en quien recayó igualmente la tarea de la pacificación, combinándose de esta forma la reducción por medios pacíficos propugnada por los religiosos y la pacificación por la fuerza impulsada por el gobernador, facultad que le fue

${ }^{45}$ AGN, Historia eclesiástica, 15, fs. $250 \mathrm{v}$ y 259 r. El documento es un "Testimonio de los utos originales que se remiten a su majestad sobre la defensa de la inmunidad eclesiástica". Sobre el movimiento cocina de 1701 no se ha podido encontrar evidencia documental en el AGN. ${ }_{46}^{4}$ AGN, Historia Eclesiâstica, 15, f. 259r.

${ }^{47}$ Ibid., f. 212 .

${ }^{48}$ Ibid.

${ }^{49}$ AGN, Caciques e indios, 33, fs. 590-592, año 1717

50 "Real cédula sobre encomiendas, títulos y repartimiento de indios, y facultades de los misioneros capuchinos", en ibid., fs. 594-598. 
reconocida en una real cédula fechada en 10 de marzo de 1718, en la cual se especificaba lo siguiente:

Visto en mi Consejo de las Indias con lo que dijo mi fiscal de él, y consultándoseme sobre ello, he resuelto que la referida conquista y reducción corra a cargo de Juan Beltrān de Caycedo [...] Y respecto de que por lo que mira a puntos de declarar por conquistadores de los que ayudasen a esta reducción, repartiéndoles tierras e indios para que los sirvan [...] y así mismo le encargo solicite el descubrimiento y restablecimiento de la pesquería de perlas que se halla en aquellos parajes. ${ }^{51}$

El reconocimiento del trabajo de los capuchinos generó desacuerdos entre las instancias eclesiásticas -los capuchinos y el obispo de Santa Marta, Antonio Monroy y Meneses- por la competencia de sus jurisdicciones. La discrepancia afloró a raíz de una visita programada por el obispo a las misiones de La Cruz y San Nicolás de los Menores, a lo cual se negaron rotundamente los capuchinos de los respectivos pueblos, fray Pedro Muniesa y fray Mariano de Olocau. Éstos alegaban "que por lo que toca y mira a la visita que el señor vicario, como visitador nombrado, viene a hacer a este sitio [la Cruz], no ha lugar por [...] no ser expreso de su majestad". ${ }^{2}$ A partir de la negativa de los frailes, el obispo Monroy y Meneses excomulgó a fray Mariano de Olocau, fray Marión de Toledo y Alonso Gómez Gallego, este último vicario de Riohacha. ${ }^{53}$ El conflicto se dirimió en favor de los frailes, quienes obtuvieron el beneplácito del virrey Antonio de la Pedroza y Guerrero para extender la misión desde Maracaibo hacia territorios donde se hallaban los indios guajiros.

La característica de asentamiento "múltiple" de los indios guajiros hizo que los misioneros capuchinos adoptaran la estrategia de fundar pueblos en los cuales intentaban concentrarlos para facilitar la labor de evangelizarlos. Según fray Antonio de Alcácer, para 1724, se pacificó y fundó el pueblo de La Cruz, con más de 200 indios bautizados; San Antonio de Orino, con más de 300 almas; San Nicolás de los Menores, fundado por Mariano de Olocau en 1716, con casi 500 indios, y finalmente, San Juan del Rincón. El obispo de Santa Marta, por su parte, fundó los pueblos de San Pedro Nolasco de Salado, San Ramón de Parauje y Nuestra Señora de la Merced de Calabozo. ${ }^{54}$ En el año de 1726 , queda-

${ }_{51}^{51}$ "Real cédula que encarga la conquista, pacificación de los indios guajiros al gobernador de Santa Mar

${ }_{52} \mathrm{AGN}$, Historia eclesiâstica, 15, f. 211, año 1721.

${ }_{54}^{53}$ Ibid., f. $417 \mathrm{r}$.

${ }^{54}$ Alcácer, Misiones, 1959, pp. 99-108. Pese a sus sesgos analíticos e interpretativos, sigue siendo la única obra sobre la historia de las misiones capuchinas en Colombia. 
ron cinco pueblos de misiones entre los indios: "El pueblo de Menores, el pueblo de Orino, La Cruz, El Toco y el Palmarito. Y por controversia y pleitos que los padres tuvieron con el ilustrísimo señor obispo [Monroy] de Santa Marta, dejaron los padres capuchinos dichos pueblos y pasó el obispo clérigos regulares de curas en ellos." ${ }^{\text {55 }}$ Posteriormente, hacia el año 1736 volvieron los misioneros a la Guajira y fundaron nuevamente en el sitio de Menores el pueblo de Boronota; el Toco, con el nombre del Rincón de Cayus; San José de Leonisa (La Cruz) y San Francisco de Orino. Para 1755 el pueblo de Boronata tenía 438 habitantes "en otros 200 y más bautizados de este pueblo que andaban apostados y fugitivos por los montes y bosques, sin jamás venir al pueblo, por la ninguna sujeción y libertad con que viven sin apremio de sus cabezas de justicia." ${ }^{" 56}$ Este poblado prácticamente era de mestizos y tenía una tasa relativamente alta de esclavos negros. A diferencia de Boronata, el pueblo de Nuestra Señora del Socorro del Rincón de Cayus, en 1755, albergaba a 324 habitantes, "de las familias e indios puros [...] con la advertencia de que ninguno está casado legítimamente por la Iglesia sino según su ley, por la dificultad que es quitarle esta secta, comprándolas [mujeres] por una vaca o una bestia". ${ }^{57}$ El pueblo de San José Leonisa Capuchino, fundado con los indios dispersos del antiguo pueblo de La Cruz, contaba con 420 indios; Orino, fundado con los mismos indios que algún día había tenido, tenía ahora $306 .{ }^{58}$ Posteriormente, cuatro reverendos capuchinos se encaminaron hacia la Alta Guajira, en donde fundaron sendos pueblos: Macuira, Bahía Honda, Sabana del Valle y Chimare.

La labor misionera de los capuchinos en la Guajira a menudo se enfrentó a la negativa de los indios a recibirlos en sus parcialidades, otras veces tuvo que soportar su reacción violenta en los ataques de 1769 y 1775 , que contaban con el antecedente de 1724, cuando el obispo Monroy y Meneses tuvo que salir huyendo "de un sitio llamado El Salado [pueblo de San Pedro Nolasco Salado] sin poder salvar la vida de uno de sus clérigos [.... y asegurar el aprovechamiento, el que tantos años no ha podido conseguir en esta misión" ${ }^{59}$ Los informes de los misioneros hacia 1757 eran bastante pesimistas al respecto. En uno de ellos, fray Francisco de Torrente, prefecto de las misiones, indagó, por solicitud de don Juan Martínez de Escobar, comandante general de la provincia de Riohacha, con los capuchinos, fray Bacilio de Alcalá, que oficiaba en San José de

55 "Informe de los misioneros capuchinos sobre poblaciones fundadas por ellos, Censos de población", en AGN, Milicias y marina, 134, f. 395v, año 1755 .

\section{${ }_{57}$ Ibid., f. $403 \mathrm{v}$.}

${ }^{58}$ Ibid., fs. 416r y $421 \mathrm{r}$

${ }^{59} \mathrm{AGN}$, Caciques e indios, 4, f. $610 \mathrm{v}$, año 1757 
Leonisa de la Cruz, fray Bacilio de Calich, del pueblo de Nuestra Señora del Socorro del Rincón y el propio Torrente, que se desempeñaba en Boranata, "sobre la consistencia en que se halla dicha su misión, régimen y conducta con que viven los indios de ella y los demás que están dispersos en las varias parcialidades; como así propio si es vigente, útil y necesario [...] la conquista y reducción de ellos" ${ }^{60} \mathrm{El}$ interrogante solicitaba además información acerca del cacique mayor Cecilio López Sierra, sobre su conducta y su contribución a la poca reducción que se había hecho hasta el momento. ${ }^{61}$ Algunos apartes del informe suministrado por los capuchinos ilustran acerca del escaso avance de las misiones entre los indios guajiros:

y es que los indios de dichas poblaciones [Boronata, La Cruz y el Rincón], aunque tienen sus capitanes, no viven con obra a ellos, pues aunque estos les manden, no quieren obedecerlos, y lo mismo de los mandatos de los padres misioneros; vienen al catecismo los que quieren y cuando quieren, desamparando los pueblos y retirándose al monte, que les da gusto, sin que podamos remediarlo por sus genios altivos y desvergonzados, y sujetarlos a castigo; pues si les castigan sus capitanes o cualquier otro, se levanta la parentela, pidiéndoles paguen el agravio; de esto que sucede en los pueblos formados se puede inferir lo que sucederá en los que no están reducidos a pueblos de misión [...] A lo segundo decimos [...] ser tan necesaria [la conquista], que sin la dicha reducción y pacificación es inútil todo nuestro trabajo, perdiendo el tiempo y fin a que vinimos a esta provincia, que es la conversión de estas almas. ${ }^{62}$

Acerca del cacique Cecilio López Sierra informaron que permitía a los indios andar en su entera libertad, e inclusive, él era acusado de ebrio. Los frailes plantearon que su función como interlocutor entre los indios y las autoridades españolas era ambivalente, pues algunas veces los hacía asistir a la doctrina y otras no. Sin embargo, reconocían que era conveniente mantener al cacique como puente entre los indios y las autoridades españolas, pues si "fuere voz de destierro de esta provincia $u$ otro castigo de dicho cacique antes que se empiece dicha reducción, peligran las vidas de muchos españoles que solitarios andan entre los indios [y], para la de los mismos misioneros, con algunas pérdidas de bienes temporales, por robos de dichos indios". ${ }^{63}$ Finalmente, recomendaban algunas estrategias, retomadas luego por los militares en la segunda mi-

${ }^{60} \mathrm{Ibid}$, f. $608 \mathrm{r}$.

${ }^{6 !}$ Cecilio López fue cacique mayor de la nación guajira y mediador entre indios y autoridades españolas. El cargo de cacique mayor fue introducido por las autoridades hispanas y no era, pues, una forma de liderazgo entre los wayúu.

${ }^{63}$ Ibid., f. 612 r. 
tad del siglo XVIII, en el sentido de desposeer a los indios de sus armas y su ganado. Era obvia la observación de los religiosos, pues éstos eran elementos muy apreciados por las comunidades wayúu. No obstante, la recomendación de los frailes no se adoptó por considerarse extrema, "por lo que dejarlos absolutamente sin número de vacas [...] sería dejarlos a perecer, $y$ por consiguiente no tendrían ninguna seguridad las haciendas de los españoles" ${ }^{64}$ Respecto a la desposesión de sus armas, la medida era necesaria -argumentaban los frailes-, pero sólo si se complementaba con el cierre de las entradas a los extranjeros que las proveían.

La importancia de las misiones capuchinas en la península de la Guajira estuvo enmarcada principalmente a la primera mitad del siglo XviI, tiempo durante el cual su actividad sentó las bases para la constitución de la red espacial de pueblos de indios que caracterizó ese territorio a todo lo largo de la centuria. En este periodo, las tropas de la corona española no tuvieron una presencia activa en la zona, razón por la cual las tareas de pacificación, reducción y congregación de indios en pueblos recién fundados estuvieron netamente a cargo e iniciativa de los religiosos. Desde el punto de vista del poblamiento, su labor sirvió de base para la posterior refundación de varios de los pueblos de indios arrasados por el movimiento de protesta wayúu del año de 1769 . Tales reedificaciones fueron llevadas a cabo, en la segunda mitad del siglo, por la dinámica de la guerra en cabeza de las expediciones militares auspiciadas por la corona. La primera fue contratada y ejecutada por Bernardo Ruiz de Noriega; la segunda, realizada algunos años después, fue organizada directamente por el gobierno español y estuvo a cargo del brigadier Antonio de Arévalo (véase cuadro 1).

LA GUERRA COMO ESCENARIO DE CONFRONTACIÓN ENTRE LOS HISPANOS Y EL PUEBLO WAYÚU

A partir de la segunda mitad del siglo XVIII, los misioneros capuchinos cedieron su lugar a las campañas militares en la tarea de pacificar y congregar a la población aborigen de la Guajira. Entre los elementos que determinaron esta situación están las reformas borbónicas que la monarquía española llevó a cabo por medio de una serie de transformaciones tanto en la metrópoli como en las colonias americanas, lo cual implicó una reorganización administrativa del imperio colonial. La dinastía borbónica creó un Estado centralizado, burocrático y abocado al principio del engrandecimiento territorial; en este sentido, a las fuerzas arma-

${ }^{64} \mathrm{Ibid}$. 
CUADRO 1. PUEBLOS O ASENTAMIENTOS INDIGENAS DE MISIONES CAPUCHINAS EN LA GUAJIRA, 1694-1755

Pueblo o asentamiento

Boronata

La Cruz

Orino

Rincón

Parauje $^{a}$

Cercadillo

Calabazo $^{\text {a }}$

Chimare

Macuira

Ypapa (Bahía Honda)

San Pedro Nolasco de Salado ${ }^{\mathrm{a}}$
Fecha de erección

1694-1735

1716

1735

1735

1735

a Pueblos fundados por el obispo Antonio Monroy y Meneses.

Fuentes: Alcácer, Misiones, 1959; Arévalo, "Plan", 1975; Oliveros, Goajira, 1975, pp. 149 196; Rosa, Floresta, 1945.

das se les incrementó el presupuesto para la construcción de navíos de guerra en los astilleros reales, de los cuales salieron, entre 1741 y 1761, 54 barcos armados con 3688 cañones. Al terminar el reinado de Carlos III, España poseía una flota de 66 naves.

En cuanto al ejército regular, hacia 1761, contaba con casi 60000 hombres. La idea de fortalecerlo tenía como base la salvaguardia del imperio americano de los ataques extranjeros y la represión de los levantamientos internos. En 1771 se estimaba que había 42995 soldados a lo largo de Hispanoamérica, con 4851 hombres en Cuba, 2884 en Puerto Rico, 4628 en Buenos Aires, y 2759 en Cartagena. ${ }^{65}$ En cuanto a la presencia militar y estatal en la Guajira, ésta fue un espacio que contó con poca protección, lo cual favoreció la actividad de ingleses y holandeses. Si bien, desde 1715 habían comenzado las expediciones militares para someter a los indios, en cuya organización participaron los vecinos de Riohacha la presencia del Estado español vino a sentirse realmente a partir de la segunda mitad del siglo XVIII, cuando se procuró coordinar las acciones tendientes a la reducción indígena, al aprovechamiento de su mano de obra en actividades económicas y al control del territorio de la península. Propósitos en los cuales quedó patente el tratamiento de zona de frontera, caracterizada por el papel preponderante de las fuerzas militares, con

${ }^{65}$ Brading, "España", 1990, t. 2, pp. 85-126. 
lo cual algunos autores estiman que el gobierno actuó "traicionando así la actitud civil que iba en aumento, en el afán de resolver el problema de los indios no pacificados".66

La guerra en el occidente y norte de la Guajira: La "conquista" de Bernardo Ruiz de Noriega, 1760-1762

En 1760 la corona española contrató al asentista de negocios y víveres Bernardo Ruiz de Noriega, para erradicar el trato ilícito que se presentaba a lo largo de la costa, entre las bocas del río Magdalena y la laguna de Maracaibo. Además, debía pacificar y someter a los indios guajiros, para cuyo efecto le concedió el título de pacificador. Los gastos de las expediciones corrieron a cargo del titular y como contraprestación, en caso de resultados positivos, tendría el asiento de los víveres en toda la provincia del Hacha.

Al llegar a la Guajira, Ruiz entabló negociaciones con el cacique mayor Cecilio López Sierra en el pueblo de Boronata, fue padrino de óleos de una hija suya "cuya función se hizo con la mayor solemnidad y lucimiento, presenciándola los reverendos padres capuchinos y gran número de indios de varias parcialidades". ${ }^{67}$ Posteriormente hizo fijar un bando de perdón general en los pueblos de misión establecidos por los capuchinos, entre ellos el Rincón, Orino, Boronata y La Cruz. Ruiz planeaba fundar dos pueblos que sirvieran de contención tanto para los tratantes extranjeros como para los indios: Bahía Honda y la villa de San Carlos de Pedraza. El primero estaría ubicado en el extremo norte y el segundo al sur, un poco al oriente de Riohacha. Para lograr todos estos objetivos, Ruiz contaba con 1000 hombres repartidos en tres sitios: unos saldrían de Maracaibo para ocupar las faldas de los montes de Oca; otros de Valledupar y Pueblo Nuevo hacia las estribaciones de la Sierra Nevada de Santa Marta, y los últimos de Riohacha a Bahía Honda. ${ }^{68}$ Con lo cual era evidente que Ruiz quería acorralar a los guajiros desde tres frentes: norte, oeste y este; aunque paralelamente a estos planes, estableció pactos directos con los líderes de las parcialidades indígenas.

Los acuerdos estipulaban que los indios debían reconocer la religión católica, recibir a sus misioneros y proceder contra sus piaches, destruyendo los elementos para sus "diabólicas" curaciones. Dejarían de casarse

${ }^{66}$ Kuethe, "Campaña", 1987.

67 "Informe de Bernardo Ruiz de Noriega sobre su expedición contra los indios guajiros", en AGN, Milicias y marina, 124, f. 498r, año 1761.

${ }^{68}$ AGN, Milicias y marina, 124, f. 502 . 
con varias mujeres y vivirían con una, como lo ordenaba la Iglesia. Reconocerían como autoridad única terrenal la del rey y sus sucesores en la corona, al igual que acatarían las leyes que España creara, incluidas aquellas que les afectara directamente como la fundación de los pueblos que Bernardo Ruiz estimara convenientes, comprometiéndose a vivir en ellos y a echar a los españoles que estuvieran entre sus parcialidades, salvo las excepciones permitidas por las autoridades. A éstas mantendrían informadas de cuanto ocurriera en sus pueblos e irían desarmados cuando tuvieran que entrar a poblaciones de españoles. Todas las parcialidades guardarían amistad recíproca, perdonándose los agravios, y, en caso de conflicto se comprometían a usar las flechas sin "rayas envenenadas" y el fusil. Además colaborarían con sus armas y ganado en la conquista o sometimiento de los indios no reducidos o de cualquier parcialidad que se revelara. Los indios buzos que habitaban en el Carrizal al mando de Pacho Gámez se someterían a las mismas condiciones en el pueblo que se les asignara. Si se cumplían tales puntos, se les liberaría del tributo durante diez años. ${ }^{69}$

Tales condiciones reflejaban la esencia de las relaciones entre indígenas y españoles. La congregación de la población en pueblos, la aceptación de la religión y el acatamiento de las autoridades reales evidencian el deseo de sujetar a los indios perleros en un pueblo diferente para aprovechar su mano de obra en la extracción del recurso, de lo cual extraerían beneficio los comerciantes de Riohacha y las arcas reales con el pago del quinto. Por otro lado, era motivo de preocupación para las autoridades españolas los conflictos internos entre las parcialidades, puesto que retrasaban y entorpecían la pacificación general. A menudo, algunas estaban en guerra como producto de algún agravio que, de acuerdo con sus códigos culturales, merecía tal sanción.

La prohibición de que españoles vivieran entre las parcialidades indígenas tenía sentido en la medida en que se consideraba perjudicial su influencia en contra de las propias autoridades. Esta situación había sido advertida por los capuchinos en 1720, cuando fray Pedro de Muniesa en carta al obispo de Santa Marta, Antonio Monroy Meneses, planteó que: "Las setas que les van metiendo los vecinos de esta ciudad [a los indios] a los que tenemos ya inclinados a vivir debajo de la enseñanza de nuestra Santa Fe [...] pues hasta decirles, que si son blancos para tener padres, si saben para que quieren el padre vayan a rezar los niños, que no es para otra cosa sino que estando gordos los mata el padre"; más adelante señaló que "lo que yo digo públicamente, que si el rey nuestro señor quiere

69 "Tratados celebrados entre los indios y don Bernardo Ruiz de Noriega", en AGN, Gobierno civil, 7 , fs. 18-19, año 1761 . 
que a los indios guajiros se les reduzcan a nuestra ley [se deben conquistar a los moradores de esta ciudad], que los guajiros conquistados están" ${ }^{70}$

La empresa de Ruiz tuvo otros inconvenientes no menos graves. Muy pronto el indio líder de Chimare, Pablo Majusare, rompió la tregua y con ella las capitulaciones acordadas con el pacificador. ${ }^{71}$ De otra parte, comenzó una seria competencia de jurisdicciones entre Ruiz y las autoridades reales en Riohacha en cabeza del comandante de la provincia, Francisco Piñero y los miembros del Cabildo. El incidente empezó cuando Piñero invadió predios territoriales de Ruiz. Este último le aclaró a Piñero: "A vuestra majestad no conozco tenga más jurisdicción que desde el Río del Hacha a los pasos de Maroma y algunos lugares camino del Valle y está prestada porque toda la demás de esta vasta provincia está a mi orden, dirección y cuidado."72 Piñero argumentó que Ruiz obligaba a los hacendados de la provincia a acompañarlo en sus campañas de pacificación. ${ }^{73} \mathrm{El}$ pacificador tenía la facultad de repartir tierras e indios a los soldados de la hueste que participaran activamente en campañas de pacificación tal y como se había hecho entre 1715 y 1720 . Otro inconveniente lo constituyó la facultad de Ruiz para nombrar funcionarios de justicia en los terrenos denominados de la Otra Banda, correspondiente a los predios de la margen derecha del río Ranchería hasta el río Sucuy, en inmediaciones de la provincia de Maracaibo. El Cabildo de Riohacha alegaba que Ruiz no informaba a esa colectividad de sus acciones. ${ }^{74} \mathrm{El}$ pleito se agudizó por la acusación que Ruiz hizo ante el virrey en el sentido de que Piñero boicoteaba el desembarco de municiones para las expediciones contra los indios; además demoraba los auxilios para las salidas, cuando a veces no se las proporcionaba; creaba animadversión en los indios de La Cruz, el Rincón y Laguna de Fuentes contra las huestes de Ruiz y usurpaba facultades. ${ }^{75}$ Piñero en sus descargos argumentó que Ruiz sacó frutos del "país" sin discriminación alguna, además le acusaba de haber sacado

70 "Pleitos sobre defensa de inmunidades", en AGN, Historia eclesiástica 15, fs. 221-222, año 1721. 71 "El comandante Piñero informa lo acaecido con la llegada del padre Sierra en punto de la conquista de Ruiz", en AGN, Milicias y marina, 124, fs. 670-674, año 1761; Moreno y Tarazona, Materiales, 1984 , pp. 70-72.

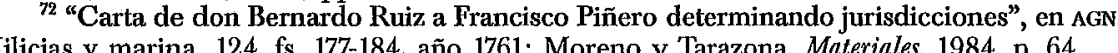
Milicias y marina, 124, fs. 177-184, año 1761; Moreno y Tarazona, Materiales, 1984, p. 64.

"El comandante Piñero informa lo acaecido con la llegada del padre Sierra en punto de teriales, 1984 de 71 .

74 "Acta del Cabildo de Riohacha sobre facultad de don Bernardo Ruiz de Noriega en la pacificación y reducción de los indios guajiros", en AGN, Milicias y marina, 119, fs. 102v y 104r, año $1760-1761$.

${ }_{75}$ "Cargos y hechos por don Bernardo Ruiz de Noriega al comandante de Riohacha por entorpecer su misión de pacificación de los indios guajiros. Testimonios a su favor", en AGN, Miscelánea, 52, fs. 2v a 6r y 7r, año 1761 . 
dinero prestado de las arcas reales de Riohacha y Valledupar sin haberlo restituido totalmente. ${ }^{76}$ Finalmente, en julio de 1762 , el virrey ordenó suspender la empresa de pacificación que llevaba a cabo Ruiz en la Guajira.

La empresa de pacificación de Ruiz en la Guajira tuvo inconvenientes por la competencia de jurisdicciones generada con el gobernador y el Cabildo de Riohacha. A esto se sumó el hecho de que tal empresa chocaba con los intereses locales de las autoridades, la mayoría de las veces vinculadas al comercio ilícito. El pacificador Ruiz acusaba a Piñero de permitir en las costas el contrabando abierto de los ingleses y holandeses a cambio de que sus tropas recibieran "las regalías de las balandras por el consentimiento de su anclaje y demás de ellos la tasa que tienen puesta a todo lo que se embarca, es un peso por cada mula o caballo, dos reales por cada carga de palo, un real por cada cuero". ${ }^{77}$ Desde este punto de vista la defensa jurisdiccional resultaba ser un pretexto. La empresa pacificadora de Ruiz no tuvo éxito porque a las autoridades locales no les convenía la sujeción de los indios, pues ello impediría el libre desarrollo del trato ilícito. De ahí que las capitulaciones estuvieran condenadas al fracaso. Sin embargo, de la campaña de Ruiz quedaron establecidos pueblos de indios en las llamadas Sabanas de Ypapa y Bahía Honda, en la Alta Guajira, y el pueblo de indios buzos en el Carrizal, entre el Cabo de la Vela y Riohacha. ${ }^{78}$ Pese a que el poblamiento y la tarea pacificadora fueron asignadas por las autoridades hispanas a Ruiz por medio de una contrata particular, es decir, privada, el fin en el fondo era el mismo: someter por medio de la guerra a los nativos.

\section{La "pacificación" de Antonio de Arévalo (1772-1776)}

Las acciones del ingeniero militar Antonio de Arévalo en la Guajira entre 1772 y 1776 no fueron aisladas, sino que hicieron parte de las políticas que en materia de defensa y estrategias militares impulsaron las nuevas orientaciones borbónicas. En efecto, los cambios establecidos por las reformas en esta materia fueron sustanciales: se adecuó el aparato militar basado en el control de todo el continente americano al establecimiento

${ }^{26}$ "Francisco Piñero, gobernador de Riohacha, informa al virrey sobre actuaciones de Bernardo Ruiz", en AGN, Miscelánea, 52, fs. $67 \mathrm{r}$ y $68 \mathrm{v}$, año 1761 .

77 "Acta del Cabildo de Riohacha sobre facultad de don Bernardo Ruiz de Noriega en la pacificación y reducción de los indios guajiros", en AGN, Milicias y marina, 119, fs. 102v y 104r, año 1760-61.

"Lista de los indios guajiros que don Bernardo Ruiz de Noriega ha pacificado, reducido y pueblos que ha fundado en virtud del título de Cabo Principal, 1760", en AGI, Audiencia de
Santa Fe, 1118; Tovar, Convocatoria, 1994 . 
de líneas defensivas en torno a una serie de puntos clave, pasando así de una fortificación aislada y aparentemente inexpugnable a un cordón defensivo que incluyó ciudades enteras, litorales, caminos y puertos. En el Caribe, por ejemplo, el triángulo cuyos vértices eran San Agustín de la Florida al norte, Veracruz al oeste y Cartagena de Indias al sur fue un espacio importante en los sistemas defensivos. ${ }^{79}$ Para ello, las exploraciones geográficas de la flora y la fauna realizadas en América durante la segunda mitad del siglo XVIII cumplieron no solamente una labor científica, sino también militar y estratégica. Ejemplo de este doble propósito es el trabajo realizado por Antonio de Arévalo en el Darién. ${ }^{80}$ Esta política multiplicó los informes y la elaboración de planes de defensa por parte de los funcionarios militares encargados de las plazas. Así, se tienen los de La Habana y la Florida en 1749, el de Santo Domingo en 1776 y el de Cartagena hecho por Antonio de Arévalo en $1766 .{ }^{81}$

El plan de Arévalo era un informe detallado y revelador de las posibilidades y limitaciones de la ciudad de Cartagena y de su provincia. En él exponía la situación de la jurisdicción y proponía la mejor manera de defenderla de los ataques extranjeros, así como la forma de asegurarle el suministro de alimentos vegetales y animales, para lo cual incluyó una "Razón de los hatos de ganados vacunos que se hallan desde las inmediaciones de Cartagena desde la distancia de 20 a 25 leguas de ella en el partido de tierra adentro, con expresión del número de cabezas que en ellos prudencialmente se regulan por algunos prácticos que han dado estas noticias." De igual forma proporcionó un mapa que señalaba los puntos neurálgicos de la provincia para ser defendidos en caso de un ataque enemigo. En términos generales, para Arévalo la defensa de Cartagena consistía en tomar las medidas necesarias en tiempos de paz para tener abastecida la plaza en caso de producirse un ataque extranjero que lograra cortar las comunicaciones y aislarla. ${ }^{82}$

El informe y el plan de Arévalo no fueron productos fortuitos, pues el conocimiento de la provincia estaba sustentado por su permanencia de alrededor de unos 50 años, entre 1742 y 1800 aproximadamente en Cartagena. Por otra parte, en 1761, siendo ya del cuerpo de ingenieros, participó en una expedición al Darién con el objeto de pacificar a los indígenas. ${ }^{83} \mathrm{Su}$ actuación en la Guajira, entonces, no fue improvisada,

${ }^{79}$ Gómez, Sistema, 1992, p. 13.

${ }^{81}$ Gómez, Sistema, 1992, p. 17.

${ }_{82}$ El plan de Arévalo sobre la provincia de Cartagena puede consultarse en Dorta, "Cartagena", 1962, pp. 327-352. Una reflexión sobre estos planes tambiên está en Gómez, Sistema, 1992, p. 18 .

${ }^{83}$ Salas, Ordenanzas, 1992, p. 152. 
sino que hizo parte de un plan general defensivo en todo el Caribe de Nueva Granada, en el cual estaba prevista la pacificación de los indios hostiles a la dominación hispana. Así como Arévalo elaboró un informe de diagnóstico y un plan defensivo para Cartagena, también hizo lo propio para la Guajira, su visión se materializó en un "Informe sobre la situación, condiciones materiales e historia de la provincia de Riohacha, año de 1773 " ${ }^{84}$ y un "Plan de operaciones que deberán ejecutarse en la provincia del Hacha contra los indios de ella, año de 1776". ${ }^{85}$ Ambos escritos son poco conocidos en la historiografía colonial del Caribe colombiano.

El movimiento armado wayúu de 1769 obligó a la corona española a designar al coronel Joseph Benito Encio, comandante del Batallón Fijo de Cartagena, para enfrentar los indios alzados en armas. El coronel Encio dilapidó los fondos provenientes de las arcas reales y demoró la expedición contra los guajiros, por lo cual fue relevado del mando y en su lugar se nombró al ingeniero brigadier Antonio de Arévalo, quien contaba con el respaldo de la corona, dada su experiencia en las campañas de pacificación de los indios del Darién y su conocimiento militar. Arévalo marcó una diferencia con sus predecesores en la pacificación de la península. Era consciente de la incapacidad de la guarnición de Riohacha debido a los pocos efectivos con que contaba para sujetar a los indios. En consecuencia optó, a diferencia de Ruiz y Encio, por dialogar con los líderes indígenas del movimiento de 1769 y publicar un bando de perdón general en toda la provincia. Seguidamente, liberó a los indios capturados que habían sido mandados a trabajos forzados a Cartagena por el gobernador de Riohacha, Gerónimo de Mendoza. Estos actos, acompañados con la entrega de regalos a los indios, tuvieron el fin de atraerlos y fundar nuevamente los pueblos quemados durante el movimiento: La Cruz, Rincón, Orino, Boronata y Carrizal. Los planes de Arévalo iban más allá, pues se proponía fundar cuatro poblaciones de españoles en pleno territorio guajiro: Bahía Honda, en el extremo norte; Apiesi, en el nororiente; San Bartolomé de Sinamaica, en cercanías de la laguna de Maracaibo, y la villa de San Carlos de Pedraza, al sur. El caso de Bahía Honda era parte de una estrategia consistente en ocupar un espacio estratégico, fortificarlo, y desde allí reducir por las armas al usar el castigo de grupos pequeños sin pretender la reducción de toda la comunidad indígena.

La reacción de los indios se presentó en 1775 con el ataque al pueblo de españoles llamado Apiesi, el cual fue desmantelado en su totalidad;

${ }^{84}$ "Informe sobre la situación, condiciones materiales, población e historia de la provincia de Riohacha, por don Antonio de Arévalo. Año de 1773", en AGN, Milicias y marina, 119, f. $452 \mathrm{v}$.

${ }^{85}$ Archivo del Servicio Histórico Militar, Signatura Q-7-207 (5-2-7-3). 
perecieron en la acción más de 50 soldados españoles ${ }^{86}$ Luego, en 1776 los indios atacaron Bahía Honda. La respuesta de Arévalo pasó de los medios persuasivos a la represión militar, para lo cual armó grandes contingentes de soldados, cuya misión era castigar a los indios habitantes de la serranía de la Macuira, señalados como responsables de los ataques. El desempeño de Arévalo se diferenció de sus antecesores por el uso de diversas estrategias, pero también, y esto es lo característico, porque los planes de pacificación corrieron a cargo de la misma corona española y no por contratación de particulares como fue el caso de Bernardo Ruiz de Noriega. Situación reveladora de que las autoridades hispanas comprendieron la gravedad del problema por lo cual decidieron tomar las riendas del asunto directamente.

\section{La guerra en el oriente. El lento y tortuoso camino de San Bartolomé de Sinamaica}

La fundación de la villa de San Bartolomé de Sinamaica era parte, como vimos, de una estrategia poblacional impulsada por la corona española en la segunda mitad del siglo XVIII en la Guajira, que fue emprendida por Antonio de Arévalo una vez negociada la paz con los nativos que tomaron parte en el movimiento armado de $1769 .^{87}$ Efectivamente, Arévalo proyectó la erección de cinco poblaciones de españoles en el norte y oriente de la península: Bahía Honda, la villa de San Carlos de Pedraza Apiesi, Santa Ana de Sabana del Valle y Sinamaica, poblados de carácter defensivo con el objeto de controlar las acciones de los indígenas guajiros; la población se fundó en 1774 con 63 familias que agruparon a 216 personas. ${ }^{88}$ Los problemas de seguridad ocasionados por las incursiones armadas de los guajiros y la falta de recursos de la provincia de Riohacha para mantener estas poblaciones ocasionaron la destrucción de Apiesi en 1775, el desmantelamiento de Bahía Honda y Sabana de Valle en 1799, el desmantelamiento de Pedraza en 1790 y la transferencia de Sinamaica a Maracaibo en el lapso de 1790 a $1792 .^{89}$ En estas condicio nes Sinamaica se convirtió en el punto de avanzada de la provincia de Maracaibo en territorio étnico guajiro y, por supuesto, en el único bas-

${ }^{86}$ Para los planes colonizadores de Arévalo puede mirarse su extenso informe sobre 1 provincia de Riohacha en 1773. AGN, Milicias y marina, 119, fs. 450-456.

Sobre este suceso véanse Polo "Protesta" 1099, cap. 2. Barrera Mestizaje, 2000, pp. 17320. Sobre el proceo poblacional a Polo "Defensa", 2000. Es útil el informe de la época de Arévalo, "Informe", 2001, pp. 216-250.

88 "Diario de operaciones núm. 25", en AGN, Historia civil, 20, f. 590v

${ }^{69}$ Ojer, Sumario, 1984, pp. 37-39. Caballero, "Relación", 1910, vol. 7, p. 200. 
tión de la Capitanía General de Venezuela, que seguiría enfrentando los mismos problemas de seguridad una vez se emprendiera de manera sistemática la sujeción de los territorios aledaños a la villa, incluidos los estratégicos del río Limón. El Limón servía de frontera natural entre el territorio étnico guajiro y la provincia de Maracaibo..$^{90}$

El traspaso de Sinamaica a Maracaibo no supuso la desaparición de los problemas de la guerra y, por lo tanto, de la seguridad, puesto que ahora tuvieron que lidiar con la presencia de huestes indígenas poderosas, similares a las que tuvo que enfrentar la provincia de Riohacha en el occidente de la península. La facción indígena del líder Yaurepara fue la encargada de frenar momentáneamente el avance colonizador que desde la villa de Sinamaica se impulsaba. Este dirigente aborigen tenía su base de apoyo en Cojoro y Parauje, y junto a su hermano Panieme podían quizás reunir unos "2 000 hombres de armas y flechas". ${ }^{91}$ La posición que ocupaba Yaurepara era estratégica por cuanto se encontraba en el camino que comunicaba a Riohacha con Maracaibo, además de contar con apoyo de las facciones indígenas que hacían presencia en los alrededores del Limón; el único poblado hispano en la zona era Sinamaica. El "capitán del camino de Maracaibo", como se le conocía a este líder, fue protagonista de la lucha que se libró entre las autoridades españolas, los colonos hispano-criollos y las facciones indias por el control de esta zona. ${ }^{92}$

Con un considerable pie de fuerza y con la ayuda de un zambo llamado Martín Rodríguez, Yaurepara estableció redes de cooperación no solamente con las facciones que dominaba, sino también con los contrabandistas ingleses que arribaban al puerto de Cojoro. Martín Rodríguez, que actuaba también de lenguaraz y, por lo tanto, como un eslabón entre las tradiciones culturales indígenas y "arijunas" (no indios), fue el encargado de funcionalizar estas redes, por lo que fue considerado por las autoridades reales como "perjudicial [...] en influir a los guajiros contra los españoles, como en solicitar contra nosotros el auxilio de los ingleses, por medio de las más activas negociaciones que personalmente pasa a practicar en Jamaica". 93

El blanco principal de Yaurepara fue la villa de Sinamaica y los alrededores del río Limón, donde interceptaban el correo oficial y captura-

${ }^{90}$ Similar función la cumplía el río Ranchería o Calancala de la parte colombiana, por lo que podríamos afirmar que el territorio étnico guajiro poseía dos fronteras naturales bien finidas: los ríos Ranchería y Limón.

${ }^{91}$ Archivo General de la Nación de Venezuela (en adelante AGNV), Gobernación y Capitanía General, LXXx, f. 320r, 1799.

${ }_{93}^{92}$ Ojer, Golfo, 1983, pp. 109-112.
AGN, Gobernación y Capitania General, Lxxx, f. 78r, 1799. 
ban ganado. ${ }^{94}$ Parte de este último iba a parar a las embarcaciones contrabandistas de los ingleses provenientes de Jamaica y de los holandeses de Curazao; las autoridades denunciaban que "con las invasiones que los indios hacen en las tierras que ocupan las haciendas de ganado, robándoselas para llevar a venderlas a esos mismos contrabandistas que los proveen de armas y municiones para perpetrar sus horrendos crímenes" ${ }^{95}$ Ante la inseguridad por la presión de Yaurepara, las autoridades de Maracaibo y la villa de Sinamaica propusieron al gobierno central venezolano fortificar el estrecho de Parauje y establecer lanchas armadas en la costa de la mencionada villa, el Mohán y el río Limón. ${ }^{96}$ Sin embargo, las autoridades también creían que podían llegar a arreglos negociados con Yaurepara, y producto de ello fue la paz que concertaron en 1799, que fue sellada con toda solemnidad entre Yaurepara, las facciones nativas que lo apoyaban, y los gobernadores de Riohacha y Maracaibo, además del comandante de la villa de Sinamaica. En esas negociaciones se llegaron a los siguientes acuerdos:

1) Que serían obligados al pago de las muertes hechas en los vecinos de Sinamaica durante la guerra, y que lo mismo se ejecutaría con los de su nación, muertos en dicha villa por los españoles.

2) Que no podía entrar [los indios] en la nominada villa con armas de ninguna clase, antes al contrario debía manifestar entrando sin ellas, la paz y amistad que tenían con los españoles y la confianza que debían hacer de la palabra de honor de los gobernadores de Maracaibo y Río Hacha, ante quienes se trataba y consolidaba la paz.

3) Que los españoles de las provincias tendrían seguridad en el tránsito y defensa por parte de ellos contra cualesquiera que los quisiese ofender en sus personas y bienes.

4) Que de esta manera y verificadas las condiciones puestas por su parte las que se reducían a pedir varios efectos que necesitaban, olvidarian todos los agravios y muertes ejecutadas en sus parientes y nacionales. ${ }^{97}$

${ }^{94} \mathrm{Ibid}$., LXVIII, f. 128r, 1797-1798. Este documento ilustra uno de los tantos intentos de los nativos en hostigar a Sinamaica, esta vez en número de 800 por una facción nativa de Cojoro cuyo mando estaba a cargo de un nativo apodado "El Negro".

${ }^{95}$ La Mariposa, 25 de junio de 1842, p. 4. AGNv, Gobernación y Capitanía General, Lxxvi, f. 215r, 1799.

${ }^{96}$ AGNV, Gobernación y Capitanía General, LxxvII, f. 265r, 1800; cviI, f. 185r, 1801; Ojer, Golfo, 1983, p. 132.

${ }^{97}$ AGNV, Indígenas, x, fs. 216-221, 1798. Este documento también es reproducido en Guzmán, Apuntaciones, 1967, pp. 228-229 (La primera edición de este texto data de 1899). Igualmente se publicó en El Zulia llustrado, 31 de enero de 1891, núm. 26, pp. 213-214. A lo largo del siglo XVIII pueden encontrarse tratados de esta naturaleza entre las autoridades españolas y facciones 
El punto cuatro es particularmente interesante porque hace mención a que los indios se reducian a pedir varios efectos que necesitaban, minimizando de esta manera un acto que en el fondo era un reconocimiento de la autonomía y el poder de las facciones de Yaurepara. Lo que se oculta detrás de este juego semántico es la negociación a que fueron llevadas las autoridades españolas, y no cualquier tipo de negociación sino una negociación en el marco del principio de reciprocidad que rige la sociedad wayúu. No se trataba entonces de pedir varios efectos que necesitaban los nativos, sino de compensaciones por agravios recibidos con anterioridad. ${ }^{98}$ La compensación entregada a Yaurepara incluía:

Una pieza de coleta con 1571/2 varas; cinco frenos; seis espejitos; una libra de avalorios; un papel de agujas; cuatro pañuelos; dos cargas talegas; cuatro corazas; cuatro cojines; cuatro pares de estribos; cinco botijuelas vacías; una gargantilla de oro con su relicario; cinco madejas de hilo de color morado; diez paquetes de panela; cinco botijuelas de aguardiente; ocho pesos en dinero efectivo; diez cuchillos; dos cargas de maíz; una talega de jayo; dos fustes; cuatro hachas; nueve frascos más de aguardiente; un bastón nuevo con su casco de oro, de peso una onza y ochava; una botijuela más de aguardiente; una cadena de oro de nueve castellanos.

Yaurepara pasó a Maracaibo donde fue agasajado por el gobernador de la provincia durante cuatro días, tiempo en que este último también se comprometió a entregar dos águilas de oro. ${ }^{100}$ Como se observa, el reconocimiento de la autonomía y de los principios consuetudinarios wayúu iban de la mano; sin embargo, hubo funcionarios que se percataron de esta situación y argumentaron que después de someter a los guajiros "nada se les concederá por vía de retribución sino como limosna voluntaria". ${ }^{101}$

La fragilidad de ese tratado se hizo manifiesta cuando las fuerzas de Yaurepara y Panieme arrasaron el sitio de Puertecitos, poco distante de la villa de Sinamaica, donde murieron cuatro colonos y un soldado de la línea,

paz con los cocinas y aliles de la Guajira oriental; al respecto véase Ojer, Golfo, 1983, p. 31. En 1761 Bernardo Ruiz, asentista de negocios y víveres y "pacificador" de la zona, pactó acuerdos con los nativos de la parte occidental; véase "Tratados celebrados entre los indios y don Bernardo Ruiz de Noriega", en AGN, Gobierno civil, 7, fs. 18-19, 1761. En 1771 Antonio de Arévalo pactó una paz negociada con los indios levantados en 1769, en AGN, Milicias y marina, 19 , Is. $450-456$.

${ }^{98}$ Este principio de compensación y reciprocidad ha sido expuesto como constante histórica, entre otros trabajos, en los de Barrera, Mestizaje, 2000, pp. 25-225; Polo, "Protesta", 1999 (Tuerra, Disputa, 2001; Paz, "Sociedad", 2002; Saler, "Principios", 1986.

${ }^{900}$ Guzid.

${ }^{101}$ AGNV, Gobernación y Capitanía General, LXXVII, fs. 155v-155r, 1799. 
además de la apropiación por parte de los nativos de unas 2000 reses. ${ }^{102}$ Anotaba el comandante de la villa, muy sorprendido por lo demás, que "en esta acción no están ya estos indios tan bárbaros como otras veces en su modo de pelear, pues vinieron a nosotros divididos en tres trozos, el uno para atacar en caso de resistencia de los ganaderos, el otro para llevar inmediatamente, y poner a salvo el ganado y el mayor cuerpo apostado en el camino de la villa al socorro de aquellos". ${ }^{103}$ Desde ese momento, las autoridades redoblaron su vigilancia sobre los alrededores de la villa y las entradas al río Limón, objetivo que sólo se lograba si se aseguraba el estrecho de Parauje, punto clave porque ocupaba un buen sitio en el Golfo de Venezuela, desde donde se divisaba ampliamente la entrada de embarcaciones provenientes del norte. Fortificar este estrecho y la villa de Sinamaica fueron dos preocupaciones de las autoridades de la provincia de Maracaibo. ${ }^{104}$ Estas acciones redundarían en la plena colonización de las tierras del Limón para impulsar el establecimiento de conucos. ${ }^{105}$ Pasaría, sin embargo, mucho tiempo antes de que la villa de Sinamaica y las tierras del Limón fueran seguras para su libre colonización y explotación, pues todavía en 1845 se discutía en el Senado y la Cámara de Representantes de Venezuela un decreto por el que se autorizaría la construcción de una trinchera en la línea de la villa. ${ }^{106}$ No obstante, Sinamaica se erigió como punto de avanzada de manera definitiva en territorio étnico guajiro, de hecho se convirtió en centro de operaciones de los organismos civiles, militares y religiosos, además atraía parte de la dinámica comercial producto del arribo de los indios para intercambiar sus productos. ${ }^{107}$

\section{CACIQUeS Y CAPITANES}

Los intentos de sujeción de la población indígena desplegados por las autoridades españolas, durante el siglo XVIII, incluyeron la vía de ganar influencia sobre sus líderes internos. Con tal fin crearon el cargo de cacique mayor de la nación guajira, que generalmente recaía sobre un indio

\section{${ }_{102}$ Ibid., fs. 221r-v.}

${ }_{104}^{103}$ "Comunicación de 3 de junio de 1800 del gobernador de Maracaibo al capitán general de Venezuela, acompañandole un importante plan para resgurdar a la provincia de los insultos de los guajiros", en Ministerio, Negociación, 1979, t. II, series B-C.

105 "Comunicación de 28 de mayo de 1801 del gobernador de Maracaibo al capitán general de Venezuela sobre las fertilísimas tierras del río Limón”, en ibid., pp. 155-158.

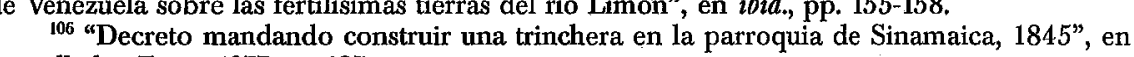
Armellada, Fuero, 1977, p. 127

$$
{ }^{107} \text { León, Relaciones, 1987, pp. 40-41. }
$$


respetado e influyente en toda la comunidad aborigen. Tal cargo no guardó relación alguna con las formas políticas de las comunidades guajiras, pues los indios estaban dispersos por toda la península, constituyendo pequeños grupos vinculados por relaciones de parentesco; cada núcleo ocupaba un determinado territorio y tenía su líder independiente y autónomo, por lo que no se puede pensar en la existencia de una jerarquía central que agrupara políticamente a todos los apüshis, si bien entre ellos había alguna asimetría económica que podía traducirse en una mayor capacidad de respuesta frente a las políticas hispanas.

El papel del cacique general era servir de puente entre los indios y las autoridades, velar por el buen desempeño de los pueblos nativos e impedir cualquier tipo de desorden en el seno de la comunidad. La creación de esta figura no tiene un seguimiento documental que permita describir su continuidad, sólo se sabe que hacia 1696 los caciques eran Juan de Amuscotegui y Luisa de Velasco, bautizados en Riohacha por el obispo de Santa Marta, Antonio Monroy y Meneses; y que estos indios eran considerados "como los principales y cabezas de todos los demás indios de esta jurisdicción, los cuales vinieron con once hijos y sobrinos suyos". ${ }^{108}$ De su desempeño no hay evidencia como tampoco la hay de la sucesión entre éstos y Cecilio López Sierra, cacique mayor de la nación guajira hacia 1750.

Francisco Pichón plantea que durante la administración del virrey José Solis (1716-1762) surgió el cacique Cecilio López Sierra, mestizo, hijo de una india noble. ${ }^{109}$ En efecto, Cecilio López era hijo de Jacinto de Sierra, blanco español que desempeñó por algún tiempo el cargo de regidor en Riohacha, y de una nativa de nombre Magdalena, del pueblo de Boronata. ${ }^{110}$ En un oficio enviado por él al rey en 1765 , en que relata sus servicios como cacique, sostiene que "por reales cédulas de 10 de agosto del año de 1702, de conferirme la gracia de capitán de infantería de los indios guajiros y de sargento mayor de la misma nación y por el excelentísimo señor don Joseph Solís la merced de maestre de campo". 11 Títulos que el cacique asumió seriamente, pues sus acciones tendieron a velar principalmente por el buen desempeño de las faenas económicas, las cuales iban desde el celo para evitar el trato ilícito hasta obligar a los indios al buceo de las perlas. En esta medida, la presencia del cacique se volvió importante, al punto de que el comandante de Riohacha informó al virrey sobre la necesidad de entenderse con el cacique Cecilio para facilitar la pacificación y reducción de los indios:

${ }^{108 ~ " D e f e n s a ~ d e ~ i n m u n i d a d e s ~ e c l e s i a ̂ s t i c a s ", ~ a n ̃ o ~ 1721, ~ e n ~ A G N, ~ H i s t o r i a ~ e c l e s i a ́ s t i c a, ~ 15, ~ f . ~ 168 v . ~}$ ${ }^{109}$ Pichón, Geografía, 1947, p. 115.

${ }_{110}$ AGN, Caciques e indios, 48 bis, fs. 246r-249v.

111 "Representación de Servicios del Cacique Cecilio López Sierra", en AGN, Milicias y marina, 124, f. 210r, año 1765 . 
Hasta la presente no he conseguido la venida a mi presencia de el cacique de los guajiros, don Cecilio, por motivo de hallarse enfermo, pero ya mejorado espero la ejecute, pues tengo concebido que este sujeto ha de ser medio para que se facilite la reducción de esta nación a población -admitiendo en cada una de ellas religioso misionero- por el dominio y séquito que tiene en ella; con cuya diligencia se logrará extinguir el continuo trato que ejercen los extranjeros en la costa, sacando la abundancia de palo de brasil y perlería que uno y otro tienen en sus tierras. $\mathrm{Y}$ teniendo como tengo noticias seguras de la docilidad e inteligencia del insinuado cacique, no desconfío poder granjearlo a mis disposiciones. ${ }^{112}$

En la reducción y fundación de pueblos de indios auspiciados por las misiones capuchinas, los religiosos se valieron del acompañamiento del cacique y de su conocimiento de los terrenos de la península. En 1762 , acompañó a fray Antonio de Alcoy, prefecto de las misiones capuchinas de Santa Marta y Riohacha, en un viaje de reconocimiento con dirección sur-norte, desde Boronata hasta Bahía Honda, recorrido que abarcó lugares como Carrizal y Manaure, donde habitaban los indios perleros, Ypapá y Bahía Hondita. ${ }^{113}$

Junto al cargo de cacique mayor, los españoles, en un intento de cooptar las autoridades propias de los grupos, nombraron capitanes de pueblos o asentamientos indios a los líderes de los respectivos apüshis, los cuales debían entenderse directamente con el cacique mayor. Así, por ejemplo, don Bernardo Ruiz de Noriega, pacificador de la Guajira,

en virtud de las facultades que me son concedidas, elijo y nombro al referido Pablo Majusare por capitân de las parcialidades que están y se hallan a su devoción en el terreno de Chimare, para que los gobierne y mande en todo y por todo [...] Al mismo tenor y con la misma fecha se le despachó título al capitán Moscote, a don Balthasar Joseph, a don Thorivio Caporinche y Santiago de Heredia; todos cabezas de parcialidad. ${ }^{114}$

De igual forma, el pacificador nombró capitán al indio Juan Jacinto en los terrenos que ocupaba Bahía Honda. ${ }^{115}$ Sin embargo, la articulación entre el cacique mayor y los capitanes de las parcialidades no funcionó

112 "Comunicación del comandante de Riohacha, Manuel Martínez de Escobar al virrey sobre su entendimiento con el cacique de los guajiros para facilitar la pacificación", en AGN, Milicias y Marina, 138, f. 906r, 1754.

${ }^{13}$ Alcácer, Misiones, 1959, pp. 145-162, en el cual se transcribe el diario que Alcoy elaborô en esa salida.

114 "Copia de títulos dados a los jefes indios por don Bernardo Ruiz de Noriega", en AGN, Milicias y marina, 119, f. 92r, año 1761.

${ }^{115} \mathrm{AGN}$, Milicias y marina, 124, f. 991r, año 1762. 
porque éstos actuaban con total independencia de aquél y de las autoridades hispanas, lo cual denota que tanto el cacique mayor como los capitanes de las parcialidades usaron y sacaron provecho del cargo asignado, pues si bien en el papel aceptaron cumplir con las políticas de dominación, en la práctica fueron agentes activos de los movimientos de protesta.

\section{LA GUERRA EN LOS WAYÚU}

La guerra fue un elemento común en las comunidades indígenas de la Guajira, de hecho fue importante en las dinámicas de recomposición de fuerzas y de poder entre los distintos clanes. Ya desde el siglo XVI el cronista Juan de Castellanos registra la vida guerrera de la Guajira, en cercanías del Cabo de la Vela:

Venían los caudillos de salvajes

Con diademas de oro coronados,

Encima superbísimos plumajes;

Los rostros de pinturas variados;

A las espaldas llenos los carcajes,

Los arcos en las manos preparados

Con tan feroz y bravo continente,

Que hacían temblar al más valiente. ${ }^{11}$

Igual observación hizo fray Pedro de Aguado, quien llegó al Nuevo Reino de Granada alrededor de 1573 y recorrió la costa atlántica, en cuya crónica describe a los aborígenes que habitaban entre Santa Marta y Riohacha como "gente belicosa y que en sus flechas ponen yerba ponzoñosa, y son gente muy crecida y lúcida". ${ }^{117}$ Pablo Ojer señala cómo los nativos de la Guajira, al despuntar el siglo XVII, asolaban los alrededores de Riohacha, de hecho el "levantamiento de los congos", sucedido en 1623 en el valle de Orino, a unos 33 kilómetros de la ciudad, muestra lo diestro que estaban estos aborígenes en la guerra. ${ }^{118}$

Durante el siglo XVIII las guerras entre clanes en la Guajira muestran que estas tenían una función importante porque redefinían las correlaciones de fuerzas y de poder en el panorama clanil. Algunos de estos clanes eran reconocidos por su poder económico y la capacidad de movilizar fuerzas apelando al parentesco extendido, tales como los de

${ }_{117}^{16}$ Castellanos, Elegias, 1962, p. 195

${ }_{118}$ Ojer, Sumario, 1984, p. 23 . 
Caporinche, Majusares y Antonio Paredes. ${ }^{119}$ "No hay en ellos cacique ni señor por vínculo ni elección, y sólo lo es el que posee mayor caudal, como el que hoy tiene el llamado Capaurinche o Toribio." ${ }^{120}$ Joseph Galluzo describía con los siguientes términos al líder nativo Antonio Paredes: "Por ser este indio el más rico de toda la nación guajira los tiene a todos acobardados, porque cuando se le antoja llama a muchos de los indios pobres que habitan en Chimare [...] tiene 18 barriles de pólvora holandesa, y con esta cortedad dice que no hay más rey que él." ${ }^{121}$

Lo que se observa es que la guerra constituía un espacio donde se movilizaban recursos en hombres, armas y animales (caballos), pero también estaba la expectativa de apoderarse de las riquezas del enemigo. Weilder Guerra ha mostrado que las disputas en la sociedad wayúu se encuentran asociadas a tres factores: la competencia por el control de las áreas territoriales y los recursos naturales que en ella hay; los procesos de jerarquización social de los que se derivan competencias por posiciones políticas, y la transgresión de normas sociales, particularmente el hurto de ganado y los homicidios. ${ }^{122}$

Basta con señalar aquí que uno de los mecanismos que relacionan los clanes ricos y pobres gira alrededor del nombre de la carne, eirruku, que se complementa con el nombre de lugar de origen; un nombre de carne común, aunque con distintos grados de parentesco, puede generar solidaridad en los clanes..$^{123}$ Las fuentes oficiales tienden sutilmente un velo sobre este aspecto, tratándolo de criminalizar: "Son falsos y vengativos con tal extremo, que si uno de una parcialidad, parentela, ranchería, pueblo, o nación les hace algun daño, se pagan de él, cuando pueden, en otro de la misma parte, aunque no sepan quién es, ni que lo hayan visto nunca, basta que sean de la parte de sus enemigos porque a todos los tienen por tales." ${ }^{124}$

119 "Diario de operaciones núm. 14, del 22 de mayo al 12 de junio de 1773", en AGN, Historia civil, leg. 20, f. 521r. Alta Guajira, con lazos de parentesco entre sí que no fueron impedimento para que en varias ocasiones entraran en guerra abierta.

${ }^{120}$ Rosa, Floresta, 1945. Las cursivas son máas.
${ }^{21}$ "Don Joseph Galluzo informa sobre la resistencia del indio Paredes", en AGN, Milicias y marina, leg. 124, fs. 735v y 737r. Las cursivas son mías.

${ }^{122}$ Guerra, Disputa, 2001, p. 86.
${ }^{129}$ Concordamos con René François Picón en la apreciación que indica que durante el siglo xVII la vida cotidiana de las comunidades wayúu se desenvolvió más en el ámbito de lo local, puesto que en los documentos oficiales, cuando identifican a alguna parcialidad lo hacen designando el "capitán" o "cacique" y el lugar donde se hallaban viviendo como anotábamos anteriormente: Joseph de Boromboro, Pacho Gámez de Carrizal, etc.; sin embargo, discrepamos en que esa centuria pues durante ciertos sucesos los indios sí debieron apelar a los lazos de parentesco esalios para solicitar solidarides como sucedió en las protestas armadas en contra de las autoridades reales y los vecinos hispano-criollos en 1769,1775 y 1785. Picón, Pasteurs, 1983.

${ }_{124} 4$
Arévalo, "Plan", 1975, p. 180; Rosa, Floresta, 1945, p. 280. 
Para 1874, Rafael Benítez mencionó a los siguientes clanes con algunas de sus características más importantes, incluyendo su ubicación y riquezas, que vale la pena citar en extenso:

Zapuanas, cocinas, cocinetas. Estos indios habitan las tierras altas de Cojoro, costa y caño de Neima, Járira, Paráuja, Aramachón, Gran Eneal y ciénagas inmediatas a Sinamaica, potreros y selvas de la parte sur. Estos indios son muy pobres, viven de la rapiña y están en guerra siempre con las demás tribus. Con este motivo son fuertes, arrojados y diestros en el manejo de las armas, por lo que los indios ricos solicitan sus servicios mercenarios y ellos se los prestan ocasionalmente, en las empresas militares, y los pagan del botin del enemigo, o con animales de la propiedad de quien los ocupa.

Los hosayúes habitan el interior y Teta de Cojoro. No tienen puerto de mar; pero son riquísimos en ganados, y bestias y la riqueza allí está tan bien distribuida que es muy raro el indio que no posee algunos.

Alpushianas. Habitan la costa de Cojoro, el Salado y Güincúa. Poseen poco ganado pero bueno, y sus caballos tienen fama de corredores. Las sierras abundan en brasil [palo brasil] y dividive [dividivi], como en monte de Oca, lo que utilizan en el tráfico costeño.

Jarariyues. Habitan el interior de Macuire.

Urianas. Éstos habitan las costas y sierras de Macuire, la parte más fértil de la península, bañada por un riachuelo que lleva el nombre del lugar, y hace excelente las tierras de pancoger. Son ricos en ganados, mayor y menor, de gran tamaño: también lo son de bestias de toda especie, pero su raza no es de las mejores.

Los purciarines. Habitan las costas del norte, de Macuire al Cabo de la Vela, en cuya extensión hay varios puertos: entre ellos los Portetes y la famosa Bahía Honda, en que se hace un comercio bastante activo, principalmente con Jamaica y Aruba. Sus riquezas consisten en ganado mayor y menor y en buenas bestias.

Los Hipuanas. Habitan la costa que se dilata del Cabo de la Vela a Tairupu: en esta distancia es que se encuentra la famosa pesca de perlas. La riqueza de estos indios, en ganados y bestias, que es considerable, estã entre ellos tan bien distribuidas $[\ldots]$

Los Hipuayúes. Habitan el interior de la costa del norte hasta cerca de Riohacha. Aunque no tienen costas, negocian con los buques extranjeros, por los puertos de la Vela y Bahía Honda; pero su mayor comercio lo hacen con Riohacha. ${ }^{125}$

Como se observa, era una sociedad clanil jerarquizada de acuerdo con el grado de riquezas que poseía, que competía por los recursos que entraban en escena cuando irrumpía la guerra. Por lo tanto, las guerras de "pacificación" introducidas por las autoridades hispanas y los vecinos

${ }^{125}$ Benítez, Guajira, 1957, pp. 32-33. 
hispano-criollos con el objeto de someterlos y controlarlos no les fue ajena, por el contrario, era parte de su vida diaria, e incluso la utilizaron para sacar provecho de ella. En efecto, en la Guajira durante el siglo XVIII, al igual que en otros espacios hispanos, se configuró una red de alianzas y rivalidades entre indígenas, autoridades reales, vecinos y extranjeros que entraban en funcionamiento de acuerdo con los intereses que se jugaban en la contienda. En ocasiones los clanes establecieron alianzas con las autoridades hispanas para lanzar guerras contra otros clanes enemigos, así como también contra los cocina. ${ }^{126}$

\section{Conclusiones}

La política borbónica de defensa y control de territorios en el Caribe de Nueva Granada durante la segunda mitad del siglo XVIII fracasó en el intento concreto de reprimir el trato ilícito y pacificar a los indios guajiros. Las medidas tomadas por las autoridades reales de Riohacha dependieron en gran parte de los socorros prestados por las provincias vecinas como Santa Marta, Valledupar y Maracaibo, las cuales a menudo se encontraban en iguales aprietos económicos que Riohacha. Las arcas reales de la provincia de Riohacha en los años de 1772 a 1775 presentaron un déficit calculado por Arévalo en 200366 pesos de plata. ${ }^{127}$ Esto afectó directamente la disponibilidad de recursos para pagar las tropas terrestres y marítimas que vigilarían desde el puerto de Riohacha hasta la ciudad de Maracaibo. Por otro lado, la península de la Guajira, territorio fronterizo abierto hacia el norte, no encontró una sólida unidad con el interior del virreinato porque, aparte de no poseer incentivos para colonizadores y aventureros debido a la naturaleza física de su territorio, los indios guajiros actuaron como disuasores de cualquier intento de su reducción y del cierre de las vías por las cuales se introducía el contrabando. En un principio, las estrategias empleadas por las autoridades españolas para pacificar a los indios fueron pensadas para una población políticamente homogénea; lo cual hizo que no tuvieran efecto alguno entre indios organizados en numerosas parcialidades independientes, pero además porque la guerra para ellos hacía parte de su vida cotidiana $y$, por lo tanto, las operaciones militares no los debilitaron. Quizás por

${ }^{126}$ AGN, Milicias y marina, 124, fs. 203-204. No es el lugar para hablar de los rituales de la guerra en los wayúu, que aparecen en numerosas fuentes, entre las cuales pueden citarse: Arévalo, "Infor en

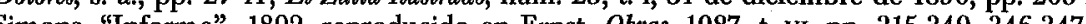
Simons, "Informe" 1892, reproducido en Ernst, Obras, 1987, t. vI, pp. 315-349, 346-347.

${ }_{127}$ Dato tomado de Arévalo, "Plan", 1975. 
ello, en la segunda mitad del siglo, recurrieron a nombrar, en calidad de capitanes, a quienes actuaban como líderes naturales de esas parcialidades indígenas. Éstos debían actuar de consuno con el "cacique mayor" Cecilio López Sierra. De esta forma se buscó superar el obstáculo de la estructura político-social de los indígenas y su característica guerrera, las cuales fueron, a la postre, elementos determinantes en el éxito de la resistencia nativa.

La situación interna de la península ayudó a que la influencia económica de ingleses y holandeses en el Caribe afianzara el eje JamaicaCurazao-Guajira como un espacio económico que consolidó el comercio ilícito en detrimento de las políticas comerciales del imperio español. Esto permitió que en la península, al igual que entre sus habitantes españoles, mestizos, negros e indios, circularan productos proporcionados por el contrabando, tráfico que desconoció el pago del arancel y afectó, de modo significativo, las arcas del virreinato.

De otro lado, la situación interna abrió espacios para que en la península de la Guajira se manifestara la pugna de España con Inglaterra y los demás países que procuraban afianzar su presencia en el Caribe. De ahí que los intentos de influencia política desplegados por las potencias rivales incluyeran la venta de armas de fuego a los indios, o su intercambio por las materias primas producidas. No es de extrañar, entonces, que elementos como el contrabando y la independencia del pueblo wayúu, rasgos típicos de una zona fronteriza del siglo XVIII, se mantuvieron intactos a lo largo de los siglos XIX y XX, prolongándose y conservándose, particularmente en la Alta Guajira, en donde el contrabando sigue siendo una forma de subsistencia para muchos de sus habitantes, indios wayúu que mantienen la vigencia de su cultura. Quienquiera que visite la Alta Guajira se dará cuenta que la dialéctica pasado-presente aún vive en esos territorios.

\section{ARCHIVOS}

AGI Archivo General de Indias.

AGN Archivo General de la Nación, Santa Fe de Bogotá.

AGNV Archivo General de la Nación de Venezuela, Caracas.

ASHM Archivo del Servicio Histórico Militar, Madrid. 


\section{HEMEROGRAFIA}

El Correo Nacional.

El Constitucional de Maracaibo.

El Zulia Ilustrado (Revista Mensual), Maracaibo.

La Mariposa, Maracaibo.

La Opinión Nacional (Diario de la Tarde), Caracas.

\section{BIBLIOGRAFÍA}

AGUADO, FRAY PEDRO DE, Recopilación historial, Bogotá, Imprenta Nacional, 1906, 480 pp. ALCÁCER, FRAY ANTONIO DE, Las misiones capuchinas en el Nuevo Reino de Granada hoy Colombia (1648-1820), Bogotá, Seminario Seráfico Misional Capuchino, 1959.

ARAÚZ MONFANTE, Celestino ANDRÉs, El contrabando holandés en el Caribe durante la primera mitad del siglo XVIIr, Caracas, Biblioteca de la Academia Nacional de la Historia, 1984, 2 tt

ARÉVALO, ANTONIO DE, "Plan de operaciones que deberá ejecutarse en la provincia del Hacha contra los indios de ella, 1776" en Marfa Teresa Oliveros, Goajira, Mérida, Venezuela, Universidad de los Andes, 1975.

"Informe sobre la situación y el estado general de la provincia del Río del Hacha, 1773" (transcripción y notas de José Polo Acuña), El Taller de la Historia, 1, Cartagena, Programa de Historia-Facultad de Ciencias Humanas-Universidad de Cartagena, 2001, pp. 213-250.

ARMELLADA, FRAY CESÁRO DE (comp.), Fuero indígena venezolano, Caracas, Instituto de Investigaciones Históricas-Universidad Católica Andrếs Bello, 1977.

Barrera Monroy, EduARDo, Mestizaje, comercio y resistencia (La Guajira durante la segunda mitad del siglo XVIII), Bogotá, Instituto Colombiano de Antropología e Historia, 2000, $246 \mathrm{pp}$.

Batista, JuAn, La estrategia española en América durante el siglo de las luces, Madrid, MAPFRE, 1992.

Bell Lemus, Gustavo, "La conexión jamaiquina y la Nueva Granada 1760-1840", Huellas, Universidad del Norte, núm. 18, 1986, Barranquilla, pp. 9-19.

Benítez, RAFAEL, La Guajira en 1874, introd. y notas de Marco-Aurelio Vila, Maracaibo, Universidad del Zulia, 1957, 45 pp.

Brading, DAVId, "La España de los borbones y su imperio americano", LeSLIE Bethell (edit.), Historia de América Latina, Barcelona, Crítica/Cambridge University, 1990, t. 2, pp. 85-126.

Caballero y Góngora, Antonio, "Relación del estado del Nuevo Reino de Granada a Francisco Gil y Lemos, 1789" en Francisco Posada y Pedro Marf́a IBÁN̂́EZ (comps.), Relaciones de mando, Bogotá, Biblioteca de Historia Nacional, 1910 , vol. 7. 
Carrocera, fray Buenaventura de, Misión de los capuchinos en Cumaná. Documentos (1735-1817), Caracas, Biblioteca de la Academia Nacional de la Historia, 1968, t. III. CASTELlanos, JuAN DE, Elegías de varones Ilustres de Indias, introd. y notas de Isaac Pardo, Caracas, Biblioteca de la Academia Nacional de la Historia, 1962, 284 pp. Clemente Batalla, Isabel, "El virreinato de la Nueva Granada y las relaciones internacionales en el Caribe", Huellas, Universidad del Norte, núm. 44, 1989, Barranquilla, pp. 18-27.

DORTA, ENRIQUe MARCO, "Cartagena de Indias: riquezas ganaderas y problemas", Tercer Congreso Hispano Americano de Historia II de Cartagena de Indias, Cartagena, Talleres Gráficos Mogollón, 1962.

ERnst, Adolfo, Obras completas, compilación por Blas Bruni Celli, Caracas, Ediciones de la Presidencia de la República, 1987, t. VI, pp. 315-485.

Fox, Robin, Sistemas de parentesco y matrimonio, Madrid, Alianza, 1979, $253 \mathrm{pp}$

GARCIA, ANTONio, Los comuneros en la pre-revolución de independencia, Bogotá, Plaza y Janés, 1981.

, "Los levantamientos goajiros" en ANTONIO GARCIA, Los comuneros en la pre-revolución de independencia, Bogotá, Plaza y Janés, 1981, pp. 119-128.

"El conflicto hispano-británico y el ordenamiento capitalista del Caribe” en Antonio GaRcía, Los comuneros en la pre-revolución de Independencia, Bogotá, Plaza y Janés, 1981, pp. 119-128.

GÓMez Pérez, CARMEN, El sistema defensivo americano siglo XVIII, Madrid, MAPfRe, 1992.

GRAHN, LANCE, "Contraband, Commerce and Society in New Granada, 1713-1763", disertación doctoral, Duke University, 1985, microfilme.

GRIMSON, ALEjANDRO, "Los procesos de fronterización: flujos, redes e historicidad" en ClaRa INÉs GaRcia (comp.), Fronteras (territorios y metáforas), Medellín, Hombre Nuevo Editores/Universidad de Antioquia, 2003, pp. 15-33.

Guerra Curvelo, WeiLder, "La ranchería de perlas del Cabo de la Vela (1538-1550)", Huellas, Universidad del Norte, núms. 49-50, 1997, Barranquilla, pp. 33-51. , La disputa y la palabra. La Ley en la sociedad wayúu, Bogotá, Ministerio de Cultura, 2001, $327 \mathrm{pp}$.

GuZMÁn, PEDRo, Apuntaciones históricas del estado Zulia, Maracaibo, Universidad del Zulia, 1967.

HeMming, JoHN, "Los indios y la frontera en el Brasil colonial" en LESLIE BETHELL (ed.), Historia de América Latina, Barcelona, Crítica/Cambridge University, 1990, t. 4, pp. 189-226.

JAHN, ALFREDO, Los aborigenes del occidente de Venezuela. Su historia, etnografia y afinidades lingǘsticas, Caracas, Litografía y Tipografía del Comercio, 1927.

Julián, Antonio, La perla de América, Provincia de Santa Marta, Bogotá, Biblioteca Popular de Cultura Colombiana, 1951.

Jusayú, Miguel Ángel y Jesús OLZa Zubiri, Diccionario sistemático de la lengua guajira, Caracas, Universidad Católica Andrés Bello/Centro de Lenguas Indígenas, $1988,199 \mathrm{pp}$ 
KUETHE, ALLAN, "La campaña pacificadora en la frontera de Riohacha (1772-1779)", Huellas, Universidad del Norte, núm. 19, 1987, Barranquilla, pp. 9-17.

León OuIVEROS, RAMÓN, Las relaciones inter-étnicas y la intervención del Estado en el territorio de la Guajira venezolana, Caracas, Facultad de Ciencias Económicas y Sociales-Universidad Central de Venezuela, 1987.

LEON SOLÍ́S, LEONARDO, "Las invasiones indígenas contra las localidades fronterizas de Buenos Aires, Cuyo y Chile, 1700-1800", Boletín Americanista, Universidad de Barcelona, núm. 36, 1986, Barcelona, pp. 75-105.

Liveros de CASTro, Marfa Teresa, Goajira, Mérida, Universidad de los Andes, 1975. LONDOÑO MOTA, JAIME, "La frontera: un concepto en construcción" en ClARA INÉS GaRcía (comp.), Fronteras (territorios y metáforas), Medellín, Ediciones Hombre Nuevo/Universidad de Antioquia, 2003, pp. 61-83.

LÓPEZ (BRISCOL), ANTONIO JOAQUIN, Dolores de una raza, Bogotá, Ecopetrol/Alcaldía Municipal de Uribia, s. a., $174 \mathrm{pp}$.

McFarlane, ANTHONY, Colombia antes de la independencia. Economía, sociedad y política bajo el dominio borbón, Bogotá, Banco de la República/El Áncora Editores, 1997. MCKEnZie, José Agustín, Así es la Guajira, Bogotá, Intercor, 1990.

Ministerio de Relaciones Exteriores de Venezuela, Negociacion de limites entre los Estados Unidos de Colombia y los Estados Unidos de Venezuela en 1874 y 1875, Caracas, Ministerio de Relaciones Exteriores, 1979, t. II, series B-C, pp. 133136 (Fronteras).

Moreno, Petra Josefina y Alberto Tarazona, Materiales para el estudio de las relaciones inter-étnicas en la Guajira, siglo XVII -Documentos y mapas-, Caracas, Biblioteca de la Academia Nacional de la Historia, 1984.

MúneRA, AlFonso, El fracaso de la nación. Región, clase y raza en el Caribe colombiano (1717-1810), Santafé de Bogotá, Banco de la República/El Áncora Editores, 1998.

NARVÁEZ Y LA TORRE, ANTONIO DE, "Informe de Antonio de Narváez y la Torre sobre la provincia de Santa Marta y Riohacha, 1778" en Sergio Euf́fas ORTIZ (comp.), Escritos de dos economistas coloniales, Bogotá, Banco de la República, 1965.

OJER, PABLo, El golfo de Venezuela. Una síntesis historica, Caracas, Universidad Central de Venezuela, 1983, $632 \mathrm{pp}$.

Sumario histórico del golfo de Venezuela, San Cristóbal, Universidad Católica del Táchira, $1984,147 \mathrm{pp}$

OLIVER, JOSÉ, "Reflexiones sobre el posible origen del wayúu (guajiro)" en GERARDO ARDILA (ed.), La Guajira (De la memoria al porvenir. Una visión antropologica), Bogotá, Universidad Nacional de Colombia, 1990, 318 pp.

OrTiZ, SERgro Elías (comp.), Escritos de dos economistas coloniales, Bogotá, Banco de la República, 1965.

OtTe, EnriQue, Las perlas del Caribe: Nueva Cádiz de Cubagua, Caracas, Fundación John Boulton, 1977.

Paz Reverol, Carmen laura, "La sociedad wayúu: modo de vida y principios consuetudinarios en el contexto republicano", El Taller de la Historia, 2, Progra- 
ma de Historia-Facultad de Ciencias Humanas-Universidad de Cartagena, 2002, pp. 47-83.

PEDRAJA, RENÉ DE LA, "La Guajira en el siglo XIX: indígenas, contrabando y carbón", Desarrollo y Sociedad, Universidad de los Andes, núm. 6, 1981, Bogotá, pp. 229-259. Pérez Van-Leenden, Francisco Justo, Wayuunaiki: estado, sociedad y contacto, Maracaibo, Universidad del Zulia/Universidad de la Guajira, 1998, 72 pp.

Pichón, Francisco, Geografía de la peninsula Guajira, Santa Marta, Escoffet, 1947.

Picón, François-RenÉ, Pasteurs du nouveau monde. Adoption de l'élevage chez les indiens guajiros, París, Éditions de la Maison des Sciences de l'Homme, 1983, pp. 76-77.

Polo ACuña, José, "Los wayúu y los cocina: dos caras diferentes de una misma moneda en la resistencia indígena en la Guajira, siglo XVIII", Anuario Colombiano de Historia Social y de la Cultura, Universidad Nacional, núm. 26, 1999, pp. 7-29. "Una mediación fallida: las acciones del cacique Cecilio López Sierra y el conflicto hispano-wayúu en la Guajira, 1750-1770", Historia Caribe, núm. 4, 1999, Barranquilla, pp. 67-76.

, "Protesta y resistencia indígena en la Guajira, 1750-1800", tesis de maestrîa en Historia, Bogotá, Universidad Nacional, 1999.

"En defensa de la tierra: poblamiento y conflicto social en la frontera Guajira (siglo XVIII)" en La Guajira (pluriétnica y multicultural), Riohacha, Fondo Mixto para la Promoción de las Artes y la Cultura de la Guajira, 2000, pp. 101140.

Posada, Francisco y Pedro Marfa Ibáñez (comps.), Relaciones de mando, Bogotá, Biblioteca de Historia Nacional, 1919, vol. 7.

ROSA, JOSÉ NiCOLÁS DE LA, Floresta de la santa iglesia catedral de la ciudad de Santo Marta, Barranquilla, Biblioteca de Autores Costeños, 1945, 365 pp.

SAlas LOPEZ, Fernando DE, Ordenanzas militares en España e Hispanoamérica, Madrid, MAPFRE, 1992.

SAlER, BENSON, "Principios de compensación y el valor de las personas en la sociedad Guajira", Montalbán, Universidad Católica Andrés Bello, nũm. 17, 1986, Caracas, pp. 53-65.

Silvestre, Francisco, Descripción del reino de Santafé de Bogoté, Bogotá, Universidad Nacional, 1968.

SimONS, FRED, "Informe sobre el territorio de la Guajira", Boletín del Ministerio de Obras Públicas de Venezuela, núms. 167 y 169, 1892, Caracas.

Tovar Pinzón, Hermes, Convocatoria al poder del número: censos y estadísticas de la Nueva Granada, 7750-1830, Santafé de Bogotá, Archivo General de la Nación, 1994.

(comp.), Convocatoria al poder del número (Censos y Estadísticas de la Nueva Granada 1750-1830), Bogotá, Archivo General de la Nación, 1994, pp. 531-539.

El imperio y sus colonias (Las cajas reales de la Nueva Granada en el siglo XVI), Bogotá, Archivo General de la Nación, 1999.

TuRNER, FREDERICK JACKSON, La frontera en la historia americana, San José, Universidad Autónoma de Centroamérica, 1986 (1a. edición, 1893). 
VÁsquez, Socorro y Hernán Darfo Correa, "Relaciones de contacto en la Guajira en el siglo xvi: wayúus y arijunas en las pesquerías de perlas en el Cabo de la Vela", informe presentado a la Pontificia Universidad Javeriana y Colciencias, Bogotă, 1988.

"Relaciones de contacto en la Guajira en el siglo xvI: wayúus y arijunas (blancos y negros) en las pesquerías de perlas del Cabo de la Vela (1540-1570)", informe final de trabajo presentado a Colciencias y a la Universidad Javeriana, Bogotá, 1989.

VILlaLobos, SERGIO, La vida fronteriza en Chile, Madrid, MAPFRE, 1992.

WEBER, DAVID, La frontera española en America del Norte, México, FCE, 2000, 597 pp. (1a edición en español).

y JANE RAUSCH (eds.), Where Cultures Meet (Frontiers in Latin American History), Willmington, Jaguar Books, 1994, 223 pp. 


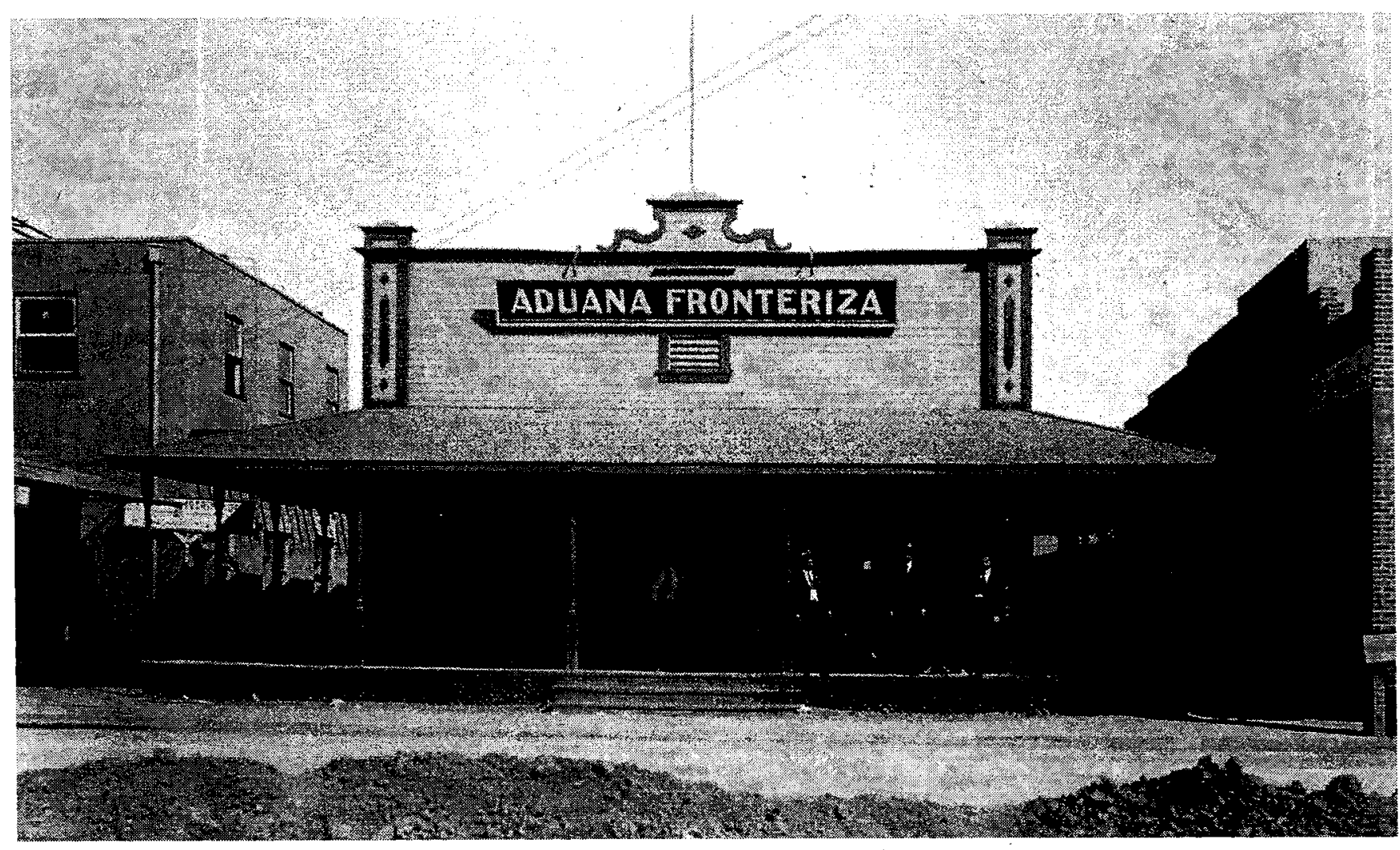

Tomada de Enrique Florescano (coord.), Historia General de las Aduanas en México, México, Confederación de Asociaciones de Agentes Aduanales de la República Mexicana (CAAAREM), 2004, p. 181. 